\title{
Fungal formation of selenium and tellurium nanoparticles
}

\section{Xinjin Liang ${ }^{1,2} \cdot$ Magali Aude Marie-Jeanne Perez ${ }^{3} \cdot$ Kenneth Chinedu Nwoko ${ }^{3} \cdot$ Philipp Egbers $^{3} \cdot$ Joerg Feldmann $^{3} \cdot$ Laszlo Csetenyi ${ }^{4}$ - Geoffrey M. Gadd ${ }^{1}$ (I)}

Received: 15 April 2019 /Revised: 17 June 2019 / Accepted: 17 June 2019 / Published online: 20 July 2019

(C) The Author(s) 2019

\begin{abstract}
The fungi Aureobasidium pullulans, Mortierella humilis, Trichoderma harzianum and Phoma glomerata were used to investigate the formation of selenium- and tellurium-containing nanoparticles during growth on selenium- and tellurium-containing media. Most organisms were able to grow on both selenium- and tellurium-containing media at concentrations of $1 \mathrm{mM}$ resulting in extensive precipitation of elemental selenium and tellurium on fungal surfaces as observed by the red and black colour changes. Red or black deposits were confirmed as elemental selenium and tellurium, respectively. Selenium oxide and tellurium oxide were also found after growth of Trichoderma harzianum with $1 \mathrm{mM}$ selenite and tellurite as well as the formation of elemental selenium and tellurium. The hyphal matrix provided nucleation sites for metalloid deposition with extracellular protein and extracellular polymeric substances localizing the resultant Se or Te nanoparticles. These findings are relevant to remedial treatments for selenium and tellurium and to novel approaches for selenium and tellurium biorecovery.
\end{abstract}

Keywords Selenium $\cdot$ Tellurium $\cdot$ Nanoparticles $\cdot$ Fungi $\cdot$ Bioreduction $\cdot$ Biorecovery

\section{Introduction}

Selenium and tellurium are metalloids with chemical properties similar to sulfur, also belonging to Group 16 of the Periodic table, and both commonly occurring in - II, + IV and + VI oxidation states (Eswayah et al. 2016). Selenium and tellurium, and their related compounds, have drawn significant attention in recent years due to their properties of photoconductivity and thermoconductivity. They are classified as 'E-tech' elements and are essential components of photovoltaic solar panels, alloying agents, semiconductors

Geoffrey M. Gadd

g.m.gadd@dundee.ac.uk

1 Geomicrobiology Group, School of Life Sciences, University of Dundee, Dundee, Scotland DD1 5EH, UK

2 Present address: Sustainable Environment Research Centre, University of South Wales, Upper Glyntaff, Pontypridd, Wales CF37 4BD, UK

3 Trace Element Speciation Laboratory (TESLA), Department of Chemistry, University of Aberdeen, King's College, Meston Walk, Aberdeen, Scotland AB24 3UE, UK

4 Concrete Technology Group, Department of Civil Engineering, University of Dundee, Dundee, Scotland DD1 4HN, UK and various electronic devices being used as, e.g. copper-indium-gallium-(di)selenide (CIGS) and cadmium telluride (CdTe) (Ramanujam and Singh 2017). Se and Te are usually recovered as by-products, mostly from the anodic slimes associated with electrolytic refining of copper. Electrolytic refining employs a sulfate-based electrolyte to plate copper onto a cathode. However, this electrolyte does not dissolve base metals which leads to accumulation of, e.g. gold, tellurium, selenium, bismuth, silver and other metals, along with various refractory components at the bottom of the electrolytic cells (George 2004; Bullock et al. 2017). Remaining substrates from copper mining and refining may contain selenium at various concentrations ranging from $10-40 \%$. Tellurium concentrations are usually much lower, being around 5\% maximum (George 2004). Only 15\% of the 2700 tonnes of selenium produced each year is recycled, and most waste selenium products are discharged directly and/or indirectly into the environment, which may pose a threat to both aquatic and terrestrial environments and organisms (Haug et al. 2007).

With increasing demand and more stringent discharge regulations to limit the discharge of Se- and Te-containing wastes, the application of microbial bioprocessing could play an important role by offering cost-effective, and less chemically-based approaches. Furthermore, because of their relatively scarce abundance and low concentrations in geological repositories, 
in contrast to their high demand and potential in new technologies, and current drawbacks in traditional physico-chemical extraction methods, an understanding of microbial biorecovery of selenium and tellurium is of growing importance (Hunter and Manker 2009; Jain et al. 2014; Jacob et al. 2016).

Microorganisms are capable of transforming a range of selenium and tellurium species through oxidation, reduction, methylation and demethylation (Gadd 1993; Jacob et al. 2016; Eswayah et al. 2016). Filamentous fungi are capable of intracellular and extracellular synthesis of selenium nanoparticles, the latter making bioprocessing and biomass handling easier and providing some advantages over bacteria and other unicellular organisms (Mandal et al. 2006). The large amounts of extracellular enzymes and reductive proteins produced by fungi also provide a means for Se and Te bioreduction and biorecovery (Gharieb et al. 1995, 1999; Gharieb and Gadd 2004; Espinosa-Ortiz et al. 2015a,b, 2016a,b,c, 2017). Several naphthoquinone and anthraquinone compounds produced by T. harzianum were reported to have good reducing properties (Liu et al. 2007), and this organism was used for biomass-free extracellular synthesis of silver nanoparticles (Ahluwalia et al. 2014). Pseudomonas sp. (Hunter and Manter 2009), Alternaria alternata (Sarkar et al. 2012), Phanerochaete chrysosporium (Espinosa-Ortiz et al. 2015a,b) and Lentinula edodes (Vetchinkina et al. 2013) were able to generate selenium nanoparticles from the reduction of either selenate or selenite, while Fusarium sp., Penicillium citrinum (Gharieb et al. 1999), Saccharomyces cerevisiae (Ottosson et al. 2010), and Rhodotorula mucilaginosa (Ollivier et al. 2011) produced nanoscale elemental tellurium from tellurite. Phanerochaete chrysosporium can also produce mixed Se-Te nanoparticles when grown with selenite/ tellurite (Espinosa-Ortiz et al. 2017). Metalloid reduction can be efficient and significant amounts of metalloids can be extensively deposited around biomass. This can be more effective for removal from solution than biomethylation which may take extended time periods and result in only small amounts of removal, even from concentrated solutions, and necessitating a further trapping step to recover volatilized methylated derivatives (Brady et al. 1996; Gharieb et al. 1999; Chasteen and Bentley 2003; Nancharaiah and Lens 2015). We can hypothesise therefore that the reduction of soluble $\mathrm{Se}$ or $\mathrm{Te}$ oxyanions provides a potential route for biorecovery of these elements. Furthermore, deposited elemental forms can be of nanoscale dimensions which imbue other important physical and chemical properties of potential industrial relevance. However, in contrast to Se bioremediation, lower attention has been paid in the context of Se and Te biorecovery. Although it is known that metalloid reduction is a property found widely in microbes (Gadd 1993), detailed selection or identification of fungal species with high metalloid immobilisation efficiencies have received limited attention, nor the physical and chemical conditions necessary for optimal reduction and removal from solution. A biological treatment provides an alternative direction for biorecovery of $\mathrm{Se}$ and $\mathrm{Te}$ from solution. The use of microorganisms to convert metalloid oxyanions to less toxic elemental forms not only reduces the toxicity and bioavailability of selenium and tellurium, with well-known applications in bioremediation (Gharieb et al. 1995, 1999; Gharieb and Gadd 2004; Espinosa-Ortiz et al. 2015a, b, 2016a, b, c, 2017), but also is potentially useful for biorecovery and production of selenium and tellurium nanoparticles for technological applications (Eswayah et al. 2016; Liang and Gadd 2017).

The aim of this research was to explore the potential of selected fungal strains as selenium- and/or tellurite-reducing organisms. Specific objectives were to determine the influence of Se or Te oxyanions on fungal growth and morphology, to determine the removal efficiency of Se or Te oxyanions from solution and to characterise the products generated by metalloid-reducing fungi.

\section{Materials and methods}

\section{Organisms and media}

To examine the metalloid reduction ability of selected fungal strains, Aureobasidium pullulans (IMI 45533) (Mowll and Gadd 1984), Mortierella humilis (Linnemann ex W. Gams. TRTC 50620), Trichoderma harzianum (MTCC-3841), and Phoma glomerata ([Corda] Wollenw. and Hochapfel) were used for experiments. Some of these organisms were previously shown to have significant abilities in toxic metal and metalloid biotransformations (Grondona et al. 1997; Birla et al. 2009; Freitas et al. 2011; Gade et al. 2013; Ahluwalia et al. 2014; Siddiquee et al. 2014; Nandini et al. 2017). A. pullulans, $M$. humilis, T. harzianum and P. glomerata were routinely maintained on malt extract agar (MEA) (SigmaAldrich, St. Louis, MO, USA) for agar plate experiments and AP1 medium (detailed composition listed below) for liquid experiments. Sodium selenate anhydrous $\left(\mathrm{Na}_{2} \mathrm{SeO}_{4}\right)$ (Sigma-Aldrich, St. Louis, MO, USA), sodium selenite $\left(\mathrm{Na}_{2} \mathrm{SeO}_{3}\right.$ ) (Sigma-Aldrich, St. Louis, MO, USA) and sodium tellurite $\left(\mathrm{Na}_{2} \mathrm{TeO}_{3}\right)$ (Alfa Aesar, Lancashire, UK) were used as media additions to examine metalloid oxyanion reduction.

Liquid cultures were maintained in 250-ml Erlenmeyer conical flasks containing $100 \mathrm{ml}$ nutrient medium on an orbital shaking incubator (Infors Multitron Standard, Rittergasse, Switzerland) at $125 \mathrm{rpm}$ at $25{ }^{\circ} \mathrm{C}$ in the dark. A. pullulans, $M$. humilis, T. harzianum and $P$. glomerata were grown on AP1 agar medium for 4 days at $25^{\circ} \mathrm{C}$ prior to experimental subculture. AP1 agar medium composed the AP1 media ingredients listed below with $15 \mathrm{~g} \mathrm{~L}^{-1}$ No.1 agar (Oxford Formulation). The agar medium was adjusted to $\mathrm{pH} 5 \mathrm{using}$ $1 \mathrm{M} \mathrm{HCl}$ before autoclaving. AP1 liquid medium consisted of 


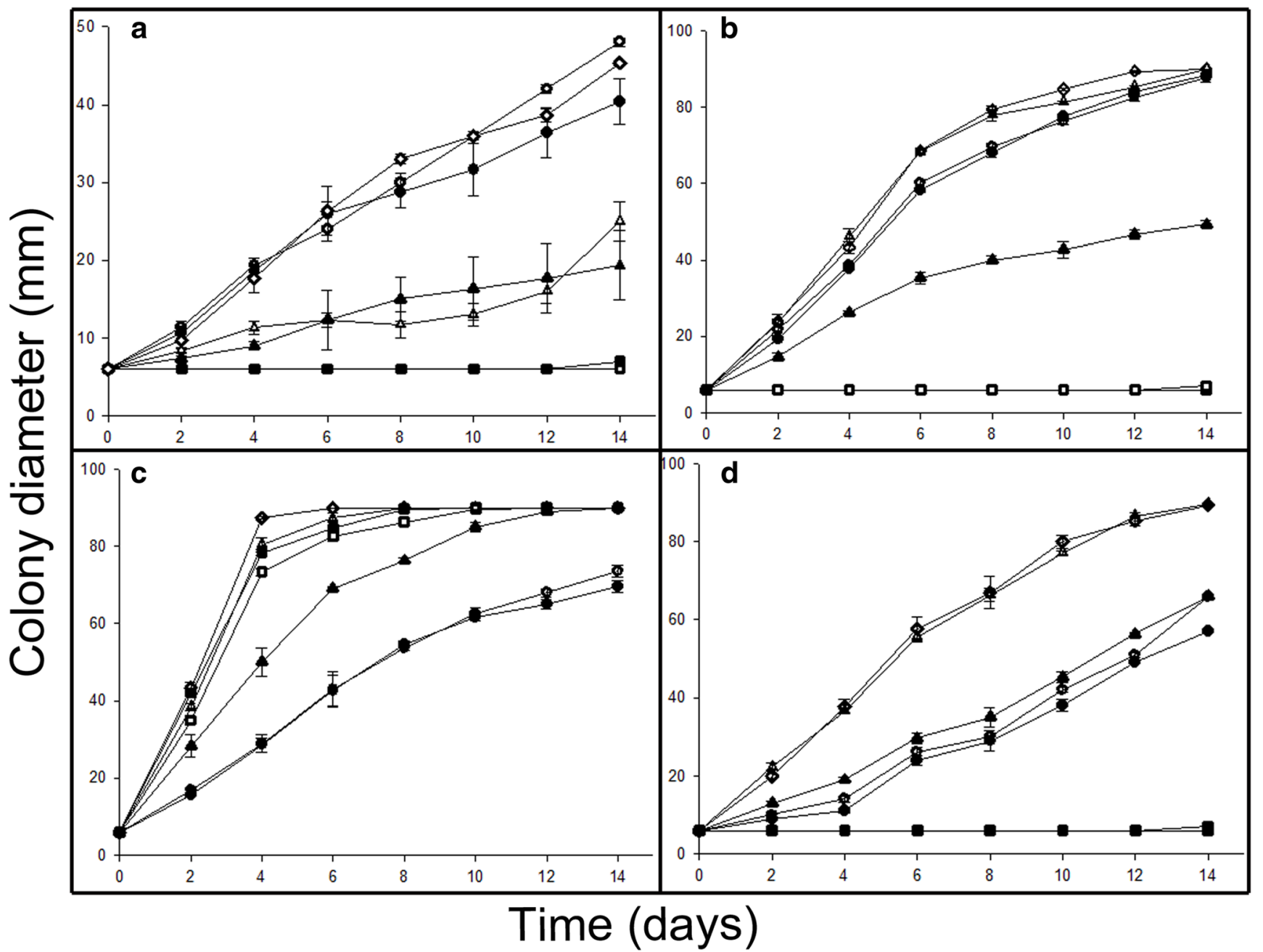

Fig. 1 Growth (colony expansion) of test fungi on $1 \mathrm{mM}$ or $5 \mathrm{mM}$ $\mathrm{Na}_{2} \mathrm{SeO}_{3^{-}}, \mathrm{Na}_{2} \mathrm{SeO}_{4^{-}}$or $\mathrm{Na}_{2} \mathrm{TeO}_{3}$-amended MEA medium. Fungal colony measurements were carried out every 2 days for (a) A. pullulans ,(b) M. humilis, (c) T. harzianum and (d) P. glomerata for 14 days. The graphs show growth on $(\mathrm{O}) 1 \mathrm{mM} \mathrm{Na}_{2} \mathrm{SeO}_{3}$, (O) $5 \mathrm{mM} \mathrm{Na}_{2} \mathrm{SeO}_{3},(\Delta)$

$1 \mathrm{mM} \mathrm{Na}_{2} \mathrm{SeO}_{4},(\boldsymbol{\Lambda}) 5 \mathrm{mM} \mathrm{Na}_{2} \mathrm{SeO}_{4}$, (口) $1 \mathrm{mM} \mathrm{Na}_{2} \mathrm{TeO}_{3}$ and $(\square$ $5 \mathrm{mM} \mathrm{Na}_{2} \mathrm{TeO}_{3}$-amended MEA medium and $(\diamond)$ MEA medium only. All test fungi were grown at $25{ }^{\circ} \mathrm{C}$ in the dark. Measurements are the mean of two diameter measurements for at least three replicates and error bars indicate the standard error of the mean

( $\mathrm{L}^{-1}$ Milli-Q water) (Merck Millipore, Billerica, Massachusetts, USA): D-glucose $30 \mathrm{~g}$ (Merck, Readington Township, NJ, USA), $\left(\mathrm{NH}_{4}\right)_{2} \mathrm{SO}_{4} 5 \mathrm{~g}$ (Sigma-Aldrich), $\mathrm{KH}_{2} \mathrm{PO}_{4} 0.5 \mathrm{~g}$ (Sigma-Aldrich), $\mathrm{MgSO}_{4} \cdot 7 \mathrm{H}_{2} \mathrm{O} 0.2 \mathrm{~g}$ (VWR, Radnor, PA, USA), $\mathrm{CaCl}_{2} \cdot 6 \mathrm{H}_{2} \mathrm{O} 0.05 \mathrm{~g}$ (VWR, Radnor, PA, USA), $\mathrm{NaCl} 0.1 \mathrm{~g}$ (Sigma-Aldrich), $\mathrm{FeCl}_{3} \cdot 6 \mathrm{H}_{2} \mathrm{O} 2.5 \mathrm{mg}$ (Sigma-Aldrich), and trace metals: $\mathrm{ZnSO}_{4} \cdot 7 \mathrm{H}_{2} \mathrm{O} 4 \mathrm{mg}$ (VWR, Radnor, PA, USA), $\mathrm{MnSO}_{4} \cdot 4 \mathrm{H}_{2} \mathrm{O} 4 \mathrm{mg}$ (VWR, Radnor, PA, USA), $\mathrm{CuSO}_{4} \cdot 5 \mathrm{H}_{2} \mathrm{O} 0.4 \mathrm{mg}$ (VWR, Radnor, PA, USA). Sodium selenite $\left(\mathrm{Na}_{2} \mathrm{SeO}_{3}\right)$, sodium selenate $\left(\mathrm{Na}_{2} \mathrm{SeO}_{4}\right)$ or sodium tellurite $\left(\mathrm{Na}_{2} \mathrm{TeO}_{3}\right)$ were dissolved separately in Milli-Q water and sterilised by membrane filtration (cellulose nitrate, $0.2-\mu \mathrm{m}$ pore diameter, Whatman, Maidstone, Kent, UK) and added to sterile AP1 medium $\left(121{ }^{\circ} \mathrm{C}, 15 \mathrm{~min}\right)$ at room temperature to give a final concentration of $1 \mathrm{mM}$. Individual AP1 media ingredients were autoclaved separately and combined when cool: the media was adjusted to $\mathrm{pH} 5$ using $1 \mathrm{M} \mathrm{HCl}$. For inoculation, ten 6mm-diameter inoculum plugs were used, taken from the margins of actively growing colonies using sterile cork borers (autoclaved at $121^{\circ} \mathrm{C}, 15 \mathrm{~min}$ ).

\section{Fungal growth in the presence of $\mathrm{Na}_{2} \mathrm{SeO}_{3}, \mathrm{Na}_{2} \mathrm{SeO}_{4}$ or $\mathrm{Na}_{2} \mathrm{TeO}_{3}$}

A. pullulans, M. humilis, T. harzianum and P. glomerata were inoculated on Se- and Te-containing malt extract agar (MEA). Sodium selenite $\left(\mathrm{Na}_{2} \mathrm{SeO}_{3}\right)$, sodium selenate $\left(\mathrm{Na}_{2} \mathrm{SeO}_{4}\right)$ or sodium tellurite $\left(\mathrm{Na}_{2} \mathrm{TeO}_{3}\right)$ were added to MEA at $50-55{ }^{\circ} \mathrm{C}$ from a sterile stock solution $\left(1 \mathrm{~mol} \mathrm{~L}^{-1}\right)$ in Milli-Q water prior to setting. Test fungi were grown on MEA plates in the dark at $25^{\circ} \mathrm{C}$ for 5 days. Disks (6-mm diameter) were then cut, using 
Table 1 Growth inhibition (GI) of the selected fungi in the presence of $\mathrm{Na}_{2} \mathrm{SeO}_{3}$ and $\mathrm{Na}_{2} \mathrm{TeO}_{3}$. Growth inhibition (GI) was derived from the diameters of fungal colonies, $\mathrm{GI}=\mathrm{D}$ (control) $-\mathrm{D}\left(\mathrm{Na}_{2} \mathrm{SeO}_{3} / \mathrm{Na}_{2} \mathrm{TeO}_{3}\right) /$ $\mathrm{D}$ (control) $-\mathrm{D}$ (original) $\times 100 \%$; $\mathrm{D}$ represents the fungal colony diameter; $\mathrm{D}$ (control) represents the expansion diameter of fungal colonies without any addition; $\mathrm{D}\left(\mathrm{Na}_{2} \mathrm{SeO}_{3} / \mathrm{Na}_{2} \mathrm{TeO}_{3}\right)$ represents the expansion diameter of fungal colonies with the addition of $\mathrm{Na}_{2} \mathrm{SeO}_{3}$ or $\mathrm{Na}_{2} \mathrm{TeO}_{3} ; \mathrm{D}$ (original) represents the original diameter of fungal colonies. For this assay, $200 \mu \mathrm{L} 20 \mathrm{mM}$ sodium selenite $\left(\mathrm{Na}_{2} \mathrm{SeO}_{3}\right)$ or sodium tellurite $\left(\mathrm{Na}_{2} \mathrm{TeO}_{3}\right)$ were added to each of four 6-mm-diameter wells located equidistant between the growing colony and the edge of the Petri dish. All test fungi were grown on MEA plates with or without $\mathrm{Na}_{2} \mathrm{SeO}_{3}$ and $\mathrm{Na}_{2} \mathrm{TeO}_{3}$ for 5 days at $25{ }^{\circ} \mathrm{C}$ in the dark. All colony diameters used in the calculations were the means of two measurements for at least three replicates

\begin{tabular}{lrr}
\hline Organism & \multicolumn{2}{c}{ Growth inhibition (\%) } \\
\cline { 2 - 3 } & \multicolumn{1}{c}{$\mathrm{Na}_{2} \mathrm{SeO}_{3}$} & \multicolumn{1}{c}{$\mathrm{Na}_{2} \mathrm{TeO}_{3}$} \\
\hline A. pullulans & $89.0 \pm 0.15$ & $53.6 \pm 0.08$ \\
M. humilis & $96.8 \pm 0.05$ & $64.5 \pm 0.07$ \\
T. harzianum & $3.0 \pm 0.11$ & $4.0 \pm 0.12$ \\
P. glomerata & $82.1 \pm 0.04$ & $28.6 \pm 0.06$ \\
\hline
\end{tabular}

a sterile cork borer, from the margins of the actively growing colonies and inoculated in the centre of triplicate test plates containing the appropriate medium without or with $\mathrm{Na}_{2} \mathrm{SeO}_{3}$, $\mathrm{Na}_{2} \mathrm{SeO}_{4}$, or $\mathrm{Na}_{2} \mathrm{TeO}_{3}$ at 1 or $5 \mathrm{mM}$. All incubations were at $25^{\circ} \mathrm{C}$ in the dark at least in triplicate. Colony diameters were measured daily in two directions to give an average diameter and measurements were discontinued when the colonies had reached the edge of the Petri dish. The ability of filamentous fungi to reduce selenite, selenate and tellurite was assessed visually, the degree of red (Se) or black (Te) colouration being used as an indicator of reduction to elemental forms.

\section{Growth inhibition in the presence of $\mathrm{Na}_{2} \mathrm{SeO}_{3}$ or $\mathrm{Na}_{2} \mathrm{TeO}_{3}$}

A. pullulans, M. humilis, T. harzianum and P. glomerata were inoculated on malt extract agar plates and incubated in the dark at $25^{\circ} \mathrm{C}$ for 5 days. Wells (6-mm diameter) were then cut in the agar at the margins of the growing colony using a sterile cork borer. $200 \mu \mathrm{L} 20 \mathrm{mM}$ sodium selenite $\left(\mathrm{Na}_{2} \mathrm{SeO}_{3}\right)$ or sodium tellurite $\left(\mathrm{Na}_{2} \mathrm{TeO}_{3}\right)$ was added to four such wells located equidistant between the growing colony and the edge of the Petri dish. Fungi grown on MEA plates without any additions were used as controls. All incubations were at $25^{\circ} \mathrm{C}$ in the dark. Colour changes and colony diameters were measured daily for a further 5 days. The ability of the fungi to reduce selenite/tellurite was again assessed visually by the degree of red or black colouration.

\section{pH change, tolerance indices and selenite and tellurite concentrations after fungal growth in Se- or Te-containing media}

To examine fungal selenite and tellurite biotransformations, test fungi were grown in $100 \mathrm{ml} \mathrm{AP1}$ liquid medium without or with $1 \mathrm{mM} \mathrm{Na}_{2} \mathrm{SeO}_{3}$ or $\mathrm{Na}_{2} \mathrm{TeO}_{3}$ in 250 -ml conical flasks on an orbital shaking incubator at $125 \mathrm{rpm}$ at $25{ }^{\circ} \mathrm{C}$ in the dark. Fungal biomass was aseptically harvested after growth for 10, 20 and 30 days by centrifugation at $4000 \mathrm{rpm}$ (4880g) for $30 \mathrm{~min}$ and washed twice with autoclaved Milli-Q water. The supernatants were further clarified by filtering through cellulose acetate membrane filters $(0.2-\mu \mathrm{m}$ pore diameter, Whatman, Maidstone, Kent, UK) at appropriate time intervals prior to analysis of selenite and tellurite concentrations and $\mathrm{pH}$. Metal tolerance was evaluated using a tolerance index (TI) calculated as follows: (dry weight of Se/Te-exposed mycelium/dry weight of control mycelium). Fungal biomass was oven-dried at $105^{\circ} \mathrm{C}$ to constant weight and then ground to a powder using a pestle and mortar (Milton Brook, Sturminster Newton, Dorset, UK).

Supernatants from fungi grown with $1 \mathrm{mM} \mathrm{Na}_{2} \mathrm{SeO}_{3}$ or $\mathrm{Na}_{2} \mathrm{TeO}_{3}$ for 10,20 or 30 days were analysed for the concentrations of selenite and tellurite remaining in solution using inductively coupled plasma mass spectrometry (ICP-MS). Total concentration measurements were performed using an inductively coupled plasma mass spectrometer 7900 (Agilent Technology, Tokyo, Japan). A solution containing $1 \mathrm{\mu g} \mathrm{L}^{-1}$ of gallium, yttrium, thallium and cerium was used to optimise lens parameters and ensure the best detection limit. Hydrogen was used as the collision gas with a flow rate of $3.5 \mathrm{~mL} \mathrm{~min}{ }^{-1}$ to prevent
Table 2 Medium $\mathrm{pH}$ and tolerance index (TI) for A. pullulans, M. humilis, T. harzianum and P. glomerata grown in AP1 medium amended with $1 \mathrm{mM} \mathrm{Na}_{2} \mathrm{SeO}_{3}$ or $\mathrm{Na}_{2} \mathrm{TeO}_{3}$. All values shown are means of at least three measurements.

\begin{tabular}{lllllll}
\hline Organism & $\mathrm{pH}$ of media after 30 days & & \multicolumn{2}{l}{ Tolerance index $(\mathrm{Rm}: \mathrm{Rc})$} \\
\cline { 2 - 3 } & Control & $(+) \mathrm{Na}_{2} \mathrm{SeO}_{3}$ & $(+) \mathrm{Na}_{2} \mathrm{TeO}_{3}$ & & $(+) \mathrm{Na}_{2} \mathrm{SeO}_{3}$ & $(+) \mathrm{Na}_{2} \mathrm{TeO}_{3}$ \\
\hline A. pullulans & $2.32 \pm 0.03$ & $2.32 \pm 0.01$ & $2.33 \pm 0.02$ & & 0.62 & 0.89 \\
M. humilis & $3.75 \pm 0.03$ & $4.41 \pm 0.02$ & $2.79 \pm 0.03$ & & 2.14 & 2.65 \\
T. harzianum & $2.40 \pm 0.01$ & $2.36 \pm 0.03$ & $2.45 \pm 0.02$ & & 2.27 & 2.53 \\
P. glomerata & $6.34 \pm 0.01$ & $5.58 \pm 0.02$ & $7.18 \pm 0.03$ & & 0.79 & 0.96 \\
\hline
\end{tabular}


Fig. 2 Concentrations of $\mathrm{Na}_{2} \mathrm{SeO}_{3}$ or $\mathrm{Na}_{2} \mathrm{TeO}_{3}$ remaining in culture supernatants after growth of test fungi in $1 \mathrm{mM}$ $\mathrm{Na}_{2} \mathrm{SeO}_{3}$ or $\mathrm{Na}_{2} \mathrm{TeO}_{3}$-amended AP1 liquid medium. (a) $\mathrm{Na}_{2} \mathrm{SeO}_{3}$ or (b) $\mathrm{Na}_{2} \mathrm{TeO}_{3}$ concentrations remaining in the culture supernatants after growth of A. pullulans, M. humilis,

T. harzianum and $P$. glomerata in AP1 media amended with $1 \mathrm{mM}$ $\mathrm{Na}_{2} \mathrm{SeO}_{3}$ or $\mathrm{Na}_{2} \mathrm{TeO}_{3}$. The bars show $\mathrm{Na}_{2} \mathrm{SeO}_{3}$ or $\mathrm{Na}_{2} \mathrm{TeO}_{3}$ concentrations in the supernatants after growth for $\square$ ( 10 days, $\square$ ( 20 days and $(\square) 30$ days. All test fungi were grown at $125 \mathrm{rpm} 25^{\circ} \mathrm{C}$ in the dark. All measurements are from at least three replicates and error bars indicate the standard error of the mean

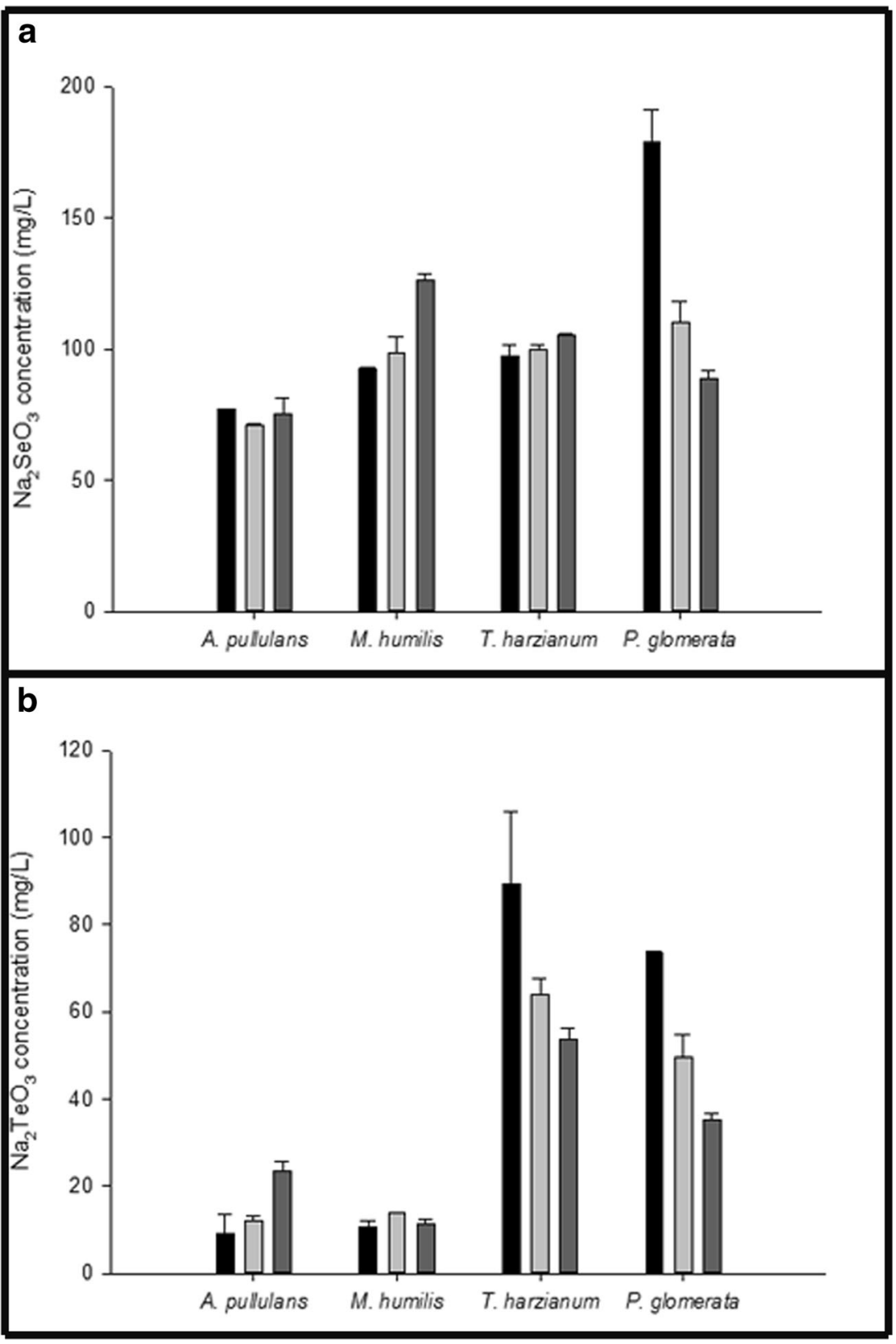

any interference which could affect selenium measurements. Selenium and tellurium standards (VWR, Radnor, PA, USA) were used at concentrations of $0,0.05,0.1,1$, 10,50 and $100 \mu \mathrm{g} \mathrm{L}^{-1}$ to perform an external calibration. Ge $\left(10 \mu \mathrm{g} \mathrm{L}^{-1}\right)$ was added inline and used as an internal standard to correct possible fluctuation of the plasma. Samples were diluted to fit in the external calibration range and spiked with $100 \mu \mathrm{L} \mathrm{HNO}_{3}(70 \%$, analytical reagent grade, Fisher Scientific, Loughborough, UK) to reach a $1 \%(v / v)$ final concentration of $\mathrm{HNO}_{3}$. For quality control, several samples were spiked with selenium and tellurium standards and a recovery close to $100 \%$ was obtained. All samples and standards were diluted/ prepared using deionised water $(18 \mathrm{M} \Omega \mathrm{cm})$.

\section{Examination of Se and Te nanoparticles produced by fungi}

Nanoparticle formation in association with fungal biomass grown with $1 \mathrm{mM} \mathrm{Na} \mathrm{SeO}_{3}$ or $\mathrm{Na}_{2} \mathrm{TeO}_{3}$ was examined using scanning electron microscopy. Fungal pellets grown in the presence of $\mathrm{Na}_{2} \mathrm{SeO}_{3}$ or $\mathrm{Na}_{2} \mathrm{TeO}_{3}$ for 30 days were cut in half using a sterile scalpel (Swann-Morton, Sheffield, UK) and fixed in $2.5 \%(v / v)$ triple-distilled glutaraldehyde in $5 \mathrm{mM}$ 1,4-piperazine $\mathrm{N}, \mathrm{N}^{\prime}$ bis (2-ethane sulphonic acid) (PIPES) buffer, $\mathrm{pH} 7.2$, for at least $24 \mathrm{~h}$ at room temperature. The $\mathrm{pH}$ of $5 \mathrm{mM}$ PIPES was adjusted using $1 \mathrm{M} \mathrm{NaOH}$ using a Corning $\mathrm{pH}$ meter 120 (Corning Incorporated, Corning, NY 14831, USA). After fixation, samples were rinsed twice in $5 \mathrm{mM}$ PIPES buffer, $\mathrm{pH} 7.2$ 
(15 min per rinse) and then dehydrated through a graded ethanol series $(50-100 \%(v / v), 15 \mathrm{~min}$ per step). Samples were then critical point dried using a liquid $\mathrm{CO}_{2}$ BAL-TEC CPD 0.30 critical point dryer (BAL-TEC company, Canonsburg, USA) and subsequently mounted on aluminium stubs using carbon adhesive tape and stored in a desiccator at room temperature. Prior to electron microscopy, samples were coated with $10 \mathrm{~nm} \mathrm{Au} / \mathrm{Pd}$ using a Cressington 208HR sputter coater (Ted Pella, Inc., Redding, CA, USA) and examined using a Philips XL30 environmental scanning electron microscope (ESEM) (Philips XL 30 ESEM FEG) operating at an accelerating voltage of $15 \mathrm{kV}$. NPs in the culture supernatants were harvested by centrifugation at speeds up to $4000 \mathrm{rpm}$ ( $4880 \mathrm{~g}$ ), each centrifugation step lasting for 30 min until the particles in the supernatant were completely separated from the biomass. Harvested particles were then washed through a graded ethanol series $(50-100 \%(v / v), 15 \mathrm{~min}$ per step), washed with sterile Milli-Q water 3 times, and subsequently mounted on aluminium stubs using carbon adhesive tape and stored in a desiccator at room temperature. Prior to electron microscopy, samples were coated with $5 \mathrm{~nm} \mathrm{Au} / \mathrm{Pd}$ and examined using a Philips XL30 environmental scanning electron microscope (ESEM) operating at an accelerating voltage of $15 \mathrm{kV}$ as described previously.

Nanoparticles formed on fungal hyphae were examined for elemental composition using energy-dispersive $\mathrm{X}$-ray analysis (EDXA) before $\mathrm{Au} / \mathrm{Pd}$ coating the samples in order to exclude the $\mathrm{Au} / \mathrm{Pd}$ peaks which overlap $\mathrm{P} / \mathrm{Cl}$ peaks. Spectra were acquired using a Phoenix EDXA analysis system embedded within the environmental scanning electron microscope (Philips XL30 ESEM FEG) operating at an accelerating voltage of $20 \mathrm{kV}$. X-ray powder diffraction (XRPD) was also used to examine the products produced. Diffraction patterns were recorded from 3 to $120^{\circ} 2-\theta$ using Ni-filtered $\mathrm{Cu} \mathrm{K}$-alpha radiation, and scanning from $3-120^{\circ} 2-\theta$ counting for 300 seconds per step on a Panalytical X-pert Pro diffractometer using a X-celerator position sensitive detector. Mineralogical phases were identified with reference to patterns in the International Centre for Diffraction Data Powder Diffraction File (PDF).

\section{Size determination and yield of Se and Te NPs}

To determine Se and/or Te particle size in the culture supernatants, the ICP-MS 7900 (Agilent Technology, Tokyo, Japan) was used in single particle mode. Supernatants were obtained by filtering through cellulose acetate membrane filters $(0.2-\mu \mathrm{m}$ pore diameter, Whatman, Maidstone, Kent, UK) and stored at $4{ }^{\circ} \mathrm{C}$ prior to analysis. In order to remove potential interferences, hydrogen was used in the collision cell at 3.5 $\mathrm{mL} \min ^{-1}$. Ionic standard solutions of the targeted elements were analysed at $0,0.05,0.1,1$ and $10 \mu \mathrm{g} \mathrm{L}^{-1}$ to determine the counts per second per $\mu \mathrm{g} \mathrm{L}^{-1}$ of each isotope measured and allow data processing. In order to calculate the nebulisation
Fig. 3 Scanning electron microscopy of nanoparticles formed by A. pullulans, $M$. humilis, $T$. harzianum, and $P$. glomerata grown in AP1 liquid media amended with $1 \mathrm{mM} \mathrm{Na} \mathrm{SeO}_{3}$ or $\mathrm{Na}_{2} \mathrm{TeO}_{3}$. A. pullulans grown in (a) $1 \mathrm{mM} \mathrm{Na}_{2} \mathrm{SeO}_{3}$ - or (b) $1 \mathrm{mM} \mathrm{Na}_{2} \mathrm{TeO}_{3}$-amended AP1 medium. Scale bars: $\mathbf{a}, \mathbf{b}=1 \mu \mathrm{m}$. The inset in $\mathbf{b}$ is a higher magnification image of the nanoparticles formed on the fungal surface (scale bar $=1 \mu \mathrm{m})$. M. humilis grown in (c) $1 \mathrm{mM} \mathrm{Na}_{2} \mathrm{SeO}_{3}$-or (d) $1 \mathrm{mM}$ $\mathrm{Na}_{2} \mathrm{TeO}_{3}$-amended AP1 medium. Scale bars: $\mathbf{a}=10 \mu \mathrm{m}, \mathbf{b}=1 \mu \mathrm{m}$. Insets in $\mathbf{c}$ and $\mathbf{d}$ are higher magnification images of the nanoparticles formed on the fungal surfaces (scale bars: $\mathrm{c}=100 \mathrm{~nm}, \mathrm{~d}=1 \mu \mathrm{m}$ ). T. harzianum grown in (e) $1 \mathrm{mM} \mathrm{Na}_{2} \mathrm{SeO}_{3^{-}}$or (f) $1 \mathrm{mM} \mathrm{Na}_{2} \mathrm{TeO}_{3}$-amended AP1 medium. Scale bars: e, $\mathbf{f}=10 \mu \mathrm{m}$. P. glomerata grown in $(\mathbf{g}) 1 \mathrm{mM}$ $\mathrm{Na}_{2} \mathrm{SeO}_{3}$ - or (h) $1 \mathrm{mM} \mathrm{Na} \mathrm{TeO}_{3}$-amended AP1 medium. Scale bars: $\mathbf{g}$, $\mathbf{h}=10 \mu \mathrm{m}$. The inset in $\mathbf{g}$ is a higher magnification image of the nanoparticles formed on the fungal surface (scale bar $=1 \mu \mathrm{m}$ ). All organisms were grown for 30 days at $25{ }^{\circ} \mathrm{C}$ in the dark on an orbital shaking incubator at $125 \mathrm{rpm}$. Typical images are shown from one of at least three examinations

efficiency, gold NP reference material RM8013 (60 nm, NIST, US) was analysed, using the same settings, at a concentration of $50 \mathrm{ng} \mathrm{L}^{-1}$. All sample dilutions and standards were prepared with deionised water $(18 \mathrm{M} \Omega \mathrm{cm})$. One isotope was monitored per sample $\left({ }^{78} \mathrm{Se},{ }^{125} \mathrm{Te}\right.$ or $\left.{ }^{197} \mathrm{Au}\right)$ for one minute. Between each sample, a rinse step of 2 min was performed with $1 \%(v / v) \mathrm{HNO}_{3}$. The dwell time was set at $0.1 \mathrm{~ms}$ and the data interpreted using MassHunter software (Agilent Technology, Tokyo, Japan).

In order to determine amounts of selenium and tellurium taken up by the fungi, selenium and tellurium were extracted from the biomass using an ammonium citrate buffer ( $\mathrm{pH} 10)$ prepared from citric acid (Sigma-Aldrich Company Ltd., Gillingham, Dorset, UK) and an ammonia solution (28\%, BDH Laboratory Supplies. Poole, Dorset, UK) used to adjust the $\mathrm{pH}$. In order to assess elemental concentration, $1 \mathrm{M}$ sodium sulphite was dissolved in citrate buffer to give the following reaction (Aborode et al. 2015):

$\mathrm{Se}^{0}{ }_{(\mathrm{s})}+\mathrm{SO}_{3}{ }^{2-}{ }_{(\mathrm{aq})} \leftrightarrows \mathrm{SeSO}_{3}{ }^{2-}{ }_{(\mathrm{aq})}$ or
$\mathrm{Te}^{0}{ }_{(\mathrm{s})}+\mathrm{SO}_{3}{ }^{2-}{ }_{(\mathrm{aq})} \leftrightarrows \mathrm{TeSO}_{3}{ }^{2-}{ }_{(\mathrm{aq})}$

The samples were extracted with regular shaking and vortexed for $2 \mathrm{~min}$ every $30 \mathrm{~min}$. After $3.5 \mathrm{~h}$, samples were centrifuged (3500 rpm (4270g), $3 \mathrm{~min}$ ) and the supernatants were collected and stored at $4{ }^{\circ} \mathrm{C}$ prior to analysis. In order to assess the amount of selenium and tellurium not extracted, the residues obtained after centrifugation were digested in $5 \mathrm{~mL}$ concentrated nitric acid (70\%) and $2 \mathrm{~mL}$ hydrogen peroxide (30\%). Samples were left for $12 \mathrm{~h}$ to pre-digest before being open-digested in a CEM Corporation Mars 5 digestion microwave oven (CEM Corporation, Matthews, NC, USA), using a 3 stage temperature program. Stage 1 consisted of a ramp to $50{ }^{\circ} \mathrm{C}(1600 \mathrm{~W})$, held for $5 \mathrm{~min}$, then stage 2 ramped to $75^{\circ} \mathrm{C}$ $(1600 \mathrm{~W})$ and held for $5 \mathrm{~min}$. Finally, stage 3 was ramped to 

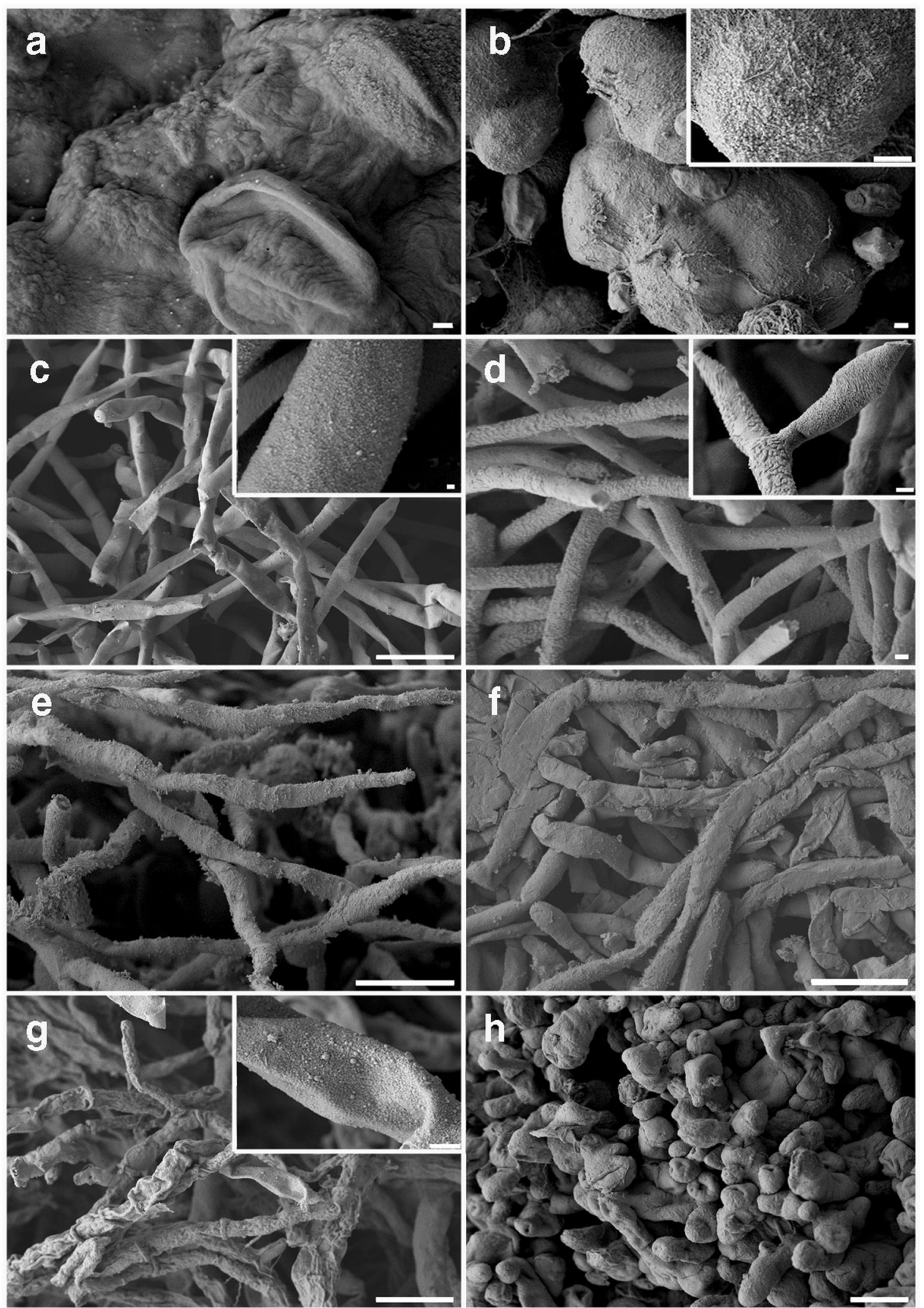

$95^{\circ} \mathrm{C}(1600 \mathrm{~W})$ and held for $30 \mathrm{~min}$ when total dissolution of the samples was observed. All samples were allowed to cool to room temperature before analysis. Total concentration analysis was performed using an inductively coupled plasma mass spectrometer 7900 (Agilent Technology, Tokyo, Japan) as described previously. 


\section{Production of extracellular protein} and exopolysaccharide during fungal growth in the presence of selenite or tellurite

To examine the possible influence of extracellular protein and exopolysaccharide on the formation of selenium and tellurium NPs, supernatants harvested after growth of selected fungal strains grown in liquid media containing $1 \mathrm{mM} \mathrm{Na}_{2} \mathrm{SeO}_{3}$ or $\mathrm{Na}_{2} \mathrm{TeO}_{3}$ for 30 days were centrifuged $(12,000 \mathrm{~g}, 20 \mathrm{~min})$ and the supernatants clarified by filtering through cellulose acetate membrane filters $(0.2-\mu \mathrm{m}$ pore diameter, Whatman, Maidstone, Kent, UK). Extracellular protein was determined using the Bradford protein assay (Bio-Rad Laboratories, Inc. Watford, UK) with bovine serum albumin as the standard. Polysaccharide content was determined by the phenolsulphuric acid method (Dubois et al. 1956), using glucose as the standard.

\section{Statistical analysis}

All data presented are means of at least three replicates: error bars represent one standard error either side of the mean. SigmaPlot, version 12.5 , was used to perform statistical analyses. Any difference in means between treatments was assessed using one-way analysis of variance (ANOVA) to a 0.05 significance level.

\section{Results}

\section{Growth on selenite-, selenate- and tellurite-containing media}

Most of the test fungi were able to grow on MEA amended with $1 \mathrm{mM} \mathrm{Na} \mathrm{TeO}_{3}$ and $\mathrm{Na}_{2} \mathrm{SeO}_{3}$, showing different degrees of black or red colouration respectively. The toxicity of $\mathrm{Na}_{2} \mathrm{TeO}_{3}$ and $\mathrm{Na}_{2} \mathrm{SeO}_{3}$ was more pronounced at a concentration of $5 \mathrm{mM}$, as indicated by reduced colony expansion rates and degree of black or red colouration. The effect of $\mathrm{Na}_{2} \mathrm{TeO}_{3}$ on A. pullulans and P. glomerata (Fig. 1a, d) was much stronger than the effect of $\mathrm{Na}_{2} \mathrm{SeO}_{3}$ at both 1 and $5 \mathrm{mM}$ concentrations. For most fungi, little or no growth occurred in the presence of $\mathrm{Na}_{2} \mathrm{SeO}_{4}$, and only M. humilis and T. harzianum were able to grow on $1 \mathrm{mM} \mathrm{Na} \mathrm{NeO}_{4}$-amended MEA. There was no significant difference in growth of M. humilis (Fig. 1b) and T. harzianum (Fig. 1c) in the presence of 1 and $5 \mathrm{mM} \mathrm{Na}_{2} \mathrm{TeO}_{3}$. Both A. pullulans (Fig. 1a) and P. glomerata (Fig. 1d) were significantly affected by $5 \mathrm{mM} \mathrm{Na}_{2} \mathrm{TeO}_{3}$.

The presence of $\mathrm{Na}_{2} \mathrm{SeO}_{3}$ and $\mathrm{Na}_{2} \mathrm{TeO}_{3}$ resulted in more than $50 \%$ growth inhibition for A. pullulans $(89 \%$ and $53.6 \%$ ) and $M$. humilis $(96.8 \%$ and $64.5 \%)$
Fig. 4 Scanning electron microscopy of nanoparticles harvested from supernatants of $A$. pullulans, $M$. humilis, T. harzianum and $P$. glomerata after growth with $1 \mathrm{mM} \mathrm{Na} \mathrm{SeO}_{3}$ or $1 \mathrm{mM} \mathrm{Na}_{2} \mathrm{TeO}_{3}$. Nanoparticles harvested from the supernatant of A. pullulans grown in (a) $1 \mathrm{mM}$ $\mathrm{Na}_{2} \mathrm{SeO}_{3}$ - or (b) $1 \mathrm{mM} \mathrm{Na}_{2} \mathrm{TeO}_{3}$-amended AP1 medium. Scale bars: a $=100 \mathrm{~nm}, \mathbf{b}=1 \mu \mathrm{m}$. Nanoparticles harvested from the supernatant of M. humilis grown in (c) $1 \mathrm{mM} \mathrm{Na}_{2} \mathrm{SeO}_{3}$ - or (d) $1 \mathrm{mM} \mathrm{Na}_{2} \mathrm{TeO}_{3}$-amended AP1 medium. Scale bars: $\mathbf{c}=100 \mathrm{~nm}, \mathbf{d}=1 \mu \mathrm{m}$. Nanoparticles harvested from supernatant of $T$. harzianum grown in (e) $1 \mathrm{mM} \mathrm{Na}_{2} \mathrm{SeO}_{3}$ - or (f) $1 \mathrm{mM} \mathrm{Na} \mathrm{TeO}_{3}$-amended AP1 medium. Scale bars: $\mathbf{e}, \mathbf{f}=1 \mu \mathrm{m}$. Nanoparticles harvested from the supernatant of $P$. glomerata grown in (g) $1 \mathrm{mM} \mathrm{Na}_{2} \mathrm{SeO}_{3}$ - or (h) $1 \mathrm{mM} \mathrm{Na}_{2} \mathrm{TeO}_{3}$-amended AP1 medium. Scale bars: $\mathbf{g}, \mathbf{h}=1 \mu \mathrm{m}$. Typical images are shown from one of at least three examinations

(Table 1). Differing effects between $\mathrm{Na}_{2} \mathrm{SeO}_{3}$ and $\mathrm{Na}_{2} \mathrm{TeO}_{3}$ were pronounced for $P$. glomerata, with $82.1 \%$ inhibition by selenite but only $28.6 \%$ from tellurite after 5 days (Table 1). T. harzianum exhibited tolerance and was little affected by the presence of $\mathrm{Na}_{2} \mathrm{SeO}_{3}$ and $\mathrm{Na}_{2} \mathrm{TeO}_{3}$ with $3 \%$ and $4 \%$ inhibition respectively (Table 1). Significant selenite and tellurite bioreduction was manifested by the red and black colony expansion rings with a marked reduction in colony expansion rates compared with the metalloid-free controls.

\section{$\mathrm{pH}$ changes and tolerance indices of experimental fungi grown in selenite- or tellurite-amended liquid media}

All fungi were able to grow in the presence of $1 \mathrm{mM}$ $\mathrm{Na}_{2} \mathrm{SeO}_{3}$ or $\mathrm{Na}_{2} \mathrm{TeO}_{3}$ over a 30-day incubation period at $25^{\circ} \mathrm{C}$. There were no significant differences in medium $\mathrm{pH}$ values on addition of $\mathrm{Na}_{2} \mathrm{SeO}_{3}$ or $\mathrm{Na}_{2} \mathrm{TeO}_{3}$ compared with the controls grown in AP1 medium except for A. pullulans and $T$. harzianum where the $\mathrm{pH}$ remained acidic ranging from $\mathrm{pH} 2.3$ to 2.4 (Table 2). The medium $\mathrm{pH}$ for M. humilis grown with $1 \mathrm{mM} \mathrm{Na} \mathrm{TeO}_{3}$ dropped to $\mathrm{pH}$ 2.8 compared with the control pH 3.8 (Table 2). The medium $\mathrm{pH}$ for $P$. glomerata grown with $1 \mathrm{mM} \mathrm{Na}_{2} \mathrm{TeO}_{3}$ resulted in a rise to $\mathrm{pH} 7.2$, while in the presence of $1 \mathrm{mM} \mathrm{Na}_{2} \mathrm{SeO}_{3}$, the $\mathrm{pH}$ dropped to $\mathrm{pH} 5.6$ compared with the control pH of 6.3 (Table 2).

In the presence of $\mathrm{Na}_{2} \mathrm{SeO}_{3}$ or $\mathrm{Na}_{2} \mathrm{TeO}_{3}$, growth of A. pullulans and P. glomerata was reduced, while $M$. humilis and $T$. harzianum showed relatively better tolerance in $\mathrm{Se} / \mathrm{Te}$-amended AP1 medium (Table 2). Tolerance indices (TI) were used to compare fungal biomass yields grown in AP1 medium with or without $1 \mathrm{mM} \mathrm{Na}_{2} \mathrm{SeO}_{3}$ or $\mathrm{Na}_{2} \mathrm{TeO}_{3}$ (Table 2). A TI value lower than 1 indicates growth inhibition, a TI value larger than 1 suggests growth stimulation. Biomass yields of A. pullulans were markedly reduced in the presence of $1 \mathrm{mM} \mathrm{Na}_{2} \mathrm{SeO}_{3}$, with growth inhibition resulting in the presence of $1 \mathrm{mM} \mathrm{Na} \mathrm{TeO}_{3}$. There was some reduction 

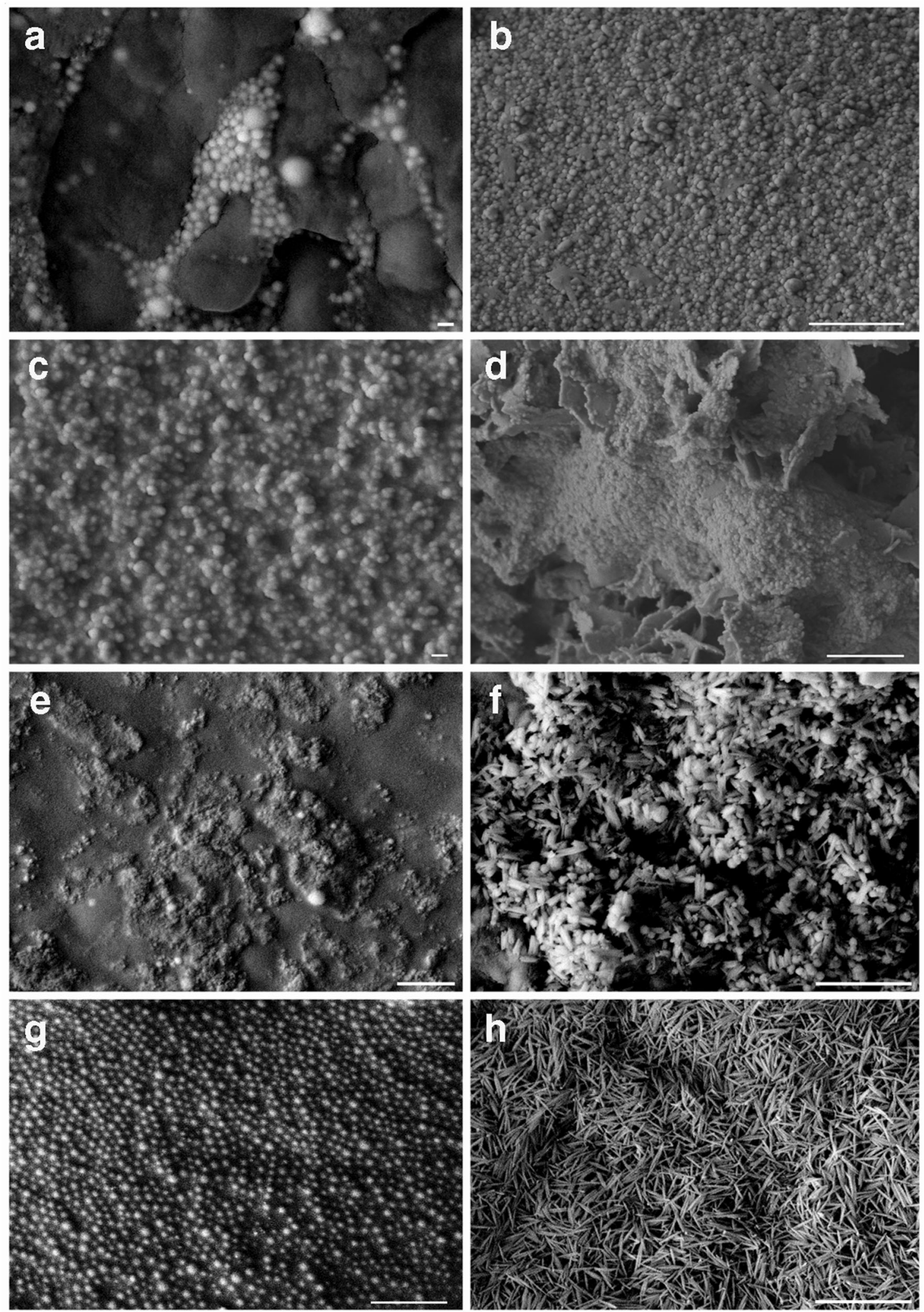

of biomass yield for P. glomerata over the first 20-day incubation in the presence of $\mathrm{Na}_{2} \mathrm{SeO}_{3}$ or $\mathrm{Na}_{2} \mathrm{TeO}_{3}$, but with a longer incubation time, biomass yields increased
(Table 2). M. humilis and T. harzianum showed higher biomass yields in the presence of $\mathrm{Na}_{2} \mathrm{SeO}_{3}$ or $\mathrm{Na}_{2} \mathrm{TeO}_{3}$ (Table 2). 


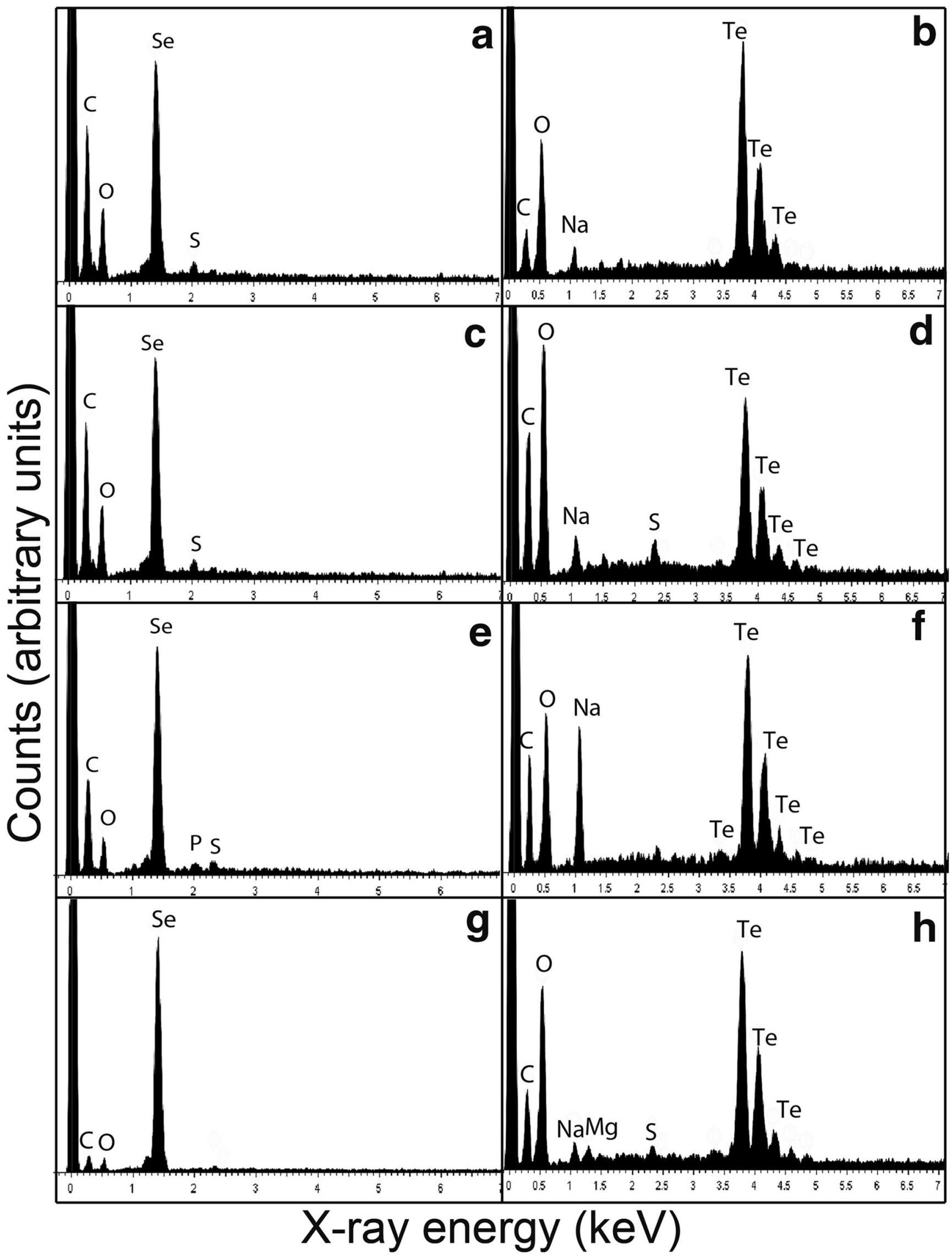


Fig. 5 EDXA of nanoparticles produced by A. pullulans, M. humilis, T. harzianum and $P$. glomerata grown in AP1 liquid media amended with $1 \mathrm{mM} \mathrm{Na} \mathrm{SeO}_{3}$ or $\mathrm{Na}_{2} \mathrm{TeO}_{3}$ for 30 days at $25^{\circ} \mathrm{C}$ in the dark on an orbital shaking incubator at $125 \mathrm{rpm}$. a, c, e, g Selenium-containing particles produced by A. pullulans, M. humilis, T. harzianum and P. glomerata (shown in Fig. 3a, c, e, g). b, d, f, h Tellurium-containing particles produced by A. pullulans, M. humilis, T. harzianum and P. glomerata (shown in Fig. $3 \mathrm{~b}, \mathrm{~d}, \mathrm{f}, \mathrm{h}$ ). Typical spectra are shown from one of at least three determinations

\section{Removal of selenite and tellurite from liquid media during fungal growth}

Fig. 2 shows the concentrations of $\mathrm{Na}_{2} \mathrm{SeO}_{3}$ or $\mathrm{Na}_{2} \mathrm{TeO}_{3}$ remaining in culture supernatants after growth of A. pullulans, M. humilis, T. harzianum and P. glomerata in AP1 medium amended with $1 \mathrm{mM}\left(172.9 \mathrm{mg} \mathrm{L}^{-1}\right)$ $\mathrm{Na}_{2} \mathrm{SeO}_{3}$ or $1 \mathrm{mM}\left(221.58 \mathrm{mg} \mathrm{L}{ }^{-1}\right) \mathrm{Na}_{2} \mathrm{TeO}_{3}$ after 10 , 20 and 30 days. There was little difference between the test strains when grown in AP1 medium with $1 \mathrm{mM}$ $\mathrm{Na}_{2} \mathrm{SeO}_{3}$, all fungi being tolerant of this selenite concentration. Remaining concentrations of selenite in the supernatant after growth for 30 days decreased from $1 \mathrm{mM}$ (172.9 $\left.\mathrm{mg} \mathrm{L}^{-1}\right)$ to around $0.58 \mathrm{mM}\left(100 \mathrm{mg} \mathrm{L}^{-1}\right)$ (Fig. 2a). For AP1 medium with $1 \mathrm{mM} \mathrm{Na}_{2} \mathrm{TeO}_{3}$, remaining concentrations of tellurite in the supernatant after growth for 30 days dropped dramatically from $1 \mathrm{mM}(221.58 \mathrm{mg}$ $\left.\mathrm{L}^{-1}\right)$ to around $0.09 \mathrm{mM}\left(20 \mathrm{mg} \mathrm{L}^{-1}\right)$ for A. pullulans and M. humilis, and $0.23 \mathrm{mM}\left(50 \mathrm{mg} \mathrm{L}^{-1}\right)$ for $T$. harzianum (Fig. 2b).

\section{Formation of elemental selenium and tellurium, and selenium- and tellurium-containing products}

Nanosized particles formed on fungal surfaces and in the medium after growth of A. pullulans, M. humilis, T. harzianum, and $P$. glomerata with $1 \mathrm{mM} \mathrm{Na}_{2} \mathrm{SeO}_{3}$ or $\mathrm{Na}_{2} \mathrm{TeO}_{3}$ (Figs. 3 and 4). Nanoparticles generated from A. pullulans, $M$. humilis and $P$. glomerata with $\mathrm{Na}_{2} \mathrm{SeO}_{3}$ were granular with similar sizes (Figs. 3 and $4 \mathrm{a}, \mathrm{c}, \mathrm{g}$ ), while particles generated by $T$. harzianum were of variable shapes (Figs. 3 and 4e), most being aggregated on the fungal surfaces (Fig. 3). Particles generated by A. pullulans, M. humilis, T. harzianum and P. glomerata after growth with $\mathrm{Na}_{2} \mathrm{TeO}_{3}$ were variable in shape and size (Figs. 3 and $4 \mathrm{~b}, \mathrm{~d}, \mathrm{f}, \mathrm{h})$. Particles generated on surfaces and in culture supernatants of $A$. pullulans and $M$. humilis were granular (Figs. 3 and $4 \mathrm{~b}, \mathrm{~d}$ ); particles harvested from M. humilis supernatant were smaller but formed aggregates (Fig. 4d); particles from A. pullulans supernatants were of similar size and well dispersed (Fig. 4b). Particles generated from T. harzianum and P. glomerata comprised pillar and needle shapes of various sizes (Fig. 4f, h), while nanorods harvested from T. harzianum supernatants clustered together being composed of numerous individual shards (Fig. 4f).

\section{Energy-dispersive X-ray analysis}

Energy-dispersive X-ray analysis (EDXA) was used to reveal the elemental composition of the particles produced by the fungi. Most particles generated after fungal growth with $1 \mathrm{mM} \mathrm{Na} \mathrm{SeO}_{3}$ showed peaks for carbon, oxygen, sulphur and selenium as the main elements (Fig. $5 \mathrm{a}, \mathrm{c}, \mathrm{e}, \mathrm{g})$. Particles generated after growth in AP1 medium amended with $1 \mathrm{mM} \mathrm{Na}_{2} \mathrm{TeO}_{3}$ showed peaks for carbon, oxygen, sodium, sulphur and tellurium as the main elements (Fig. 5b, d, f, h).

\section{Particle sizes and yields of Se and Te nanoparticles}

Both particle diameters and Se and Te NPs concentrations were determined by single particle ICP-MS (Fig. 6). The amounts of Se and Te taken up by the biomass were also determined (Table 3). Only A. pullulans and M. humilis produced Se nanoparticles after a 10-day incubation, with diameters of $\sim 60 \mathrm{~nm}$ and $\sim 48 \mathrm{~nm}$, and at concentrations of $1079 \mu \mathrm{g} \mathrm{L}^{-1}$ and $1463 \mu \mathrm{g} \mathrm{L}^{-1}$ respectively. After 20 and 30 days incubation, diameters increased to $\sim 78 \mathrm{~nm}$ and $\sim 61 \mathrm{~nm}$, with concentrations of $1885 \mu \mathrm{g} \mathrm{L}^{-1}$ and $1237 \mu \mathrm{g} \mathrm{L}^{-1}$ respectively (Fig. 6a). Low particle concentrations were detected in supernatants of T. harzianum, and P. glomerata cultures using the single particle analysis method. This may be related to the filtration step before analysis, particles possibly aggregating and being removed by the filtration. Another possibility is that elemental selenium and tellurium associated with biomass surfaces in early growth stages become dissociated after a longer incubation period.

For particles formed with $\mathrm{Na}_{2} \mathrm{TeO}_{3}$, large differences from those obtained with $\mathrm{Na}_{2} \mathrm{SeO}_{3}$ were observed. Low concentrations of nanoparticles were detected in 10-day-old fungal supernatants grown with $1 \mathrm{mM} \mathrm{Na}_{2} \mathrm{TeO}_{3}$. Nanoparticles occurred in supernatants after a 20-day incubation, with most particle diameters in the range $40-70 \mathrm{~nm}$, with concentrations of particles between 80 and $200 \mu \mathrm{g} \mathrm{L}^{-1}$. P. glomerata produced the most Te NPs at more than $200 \mu \mathrm{g} \mathrm{L}^{-1}$, while A. pullulans produced the least Te NPs at $79 \mu \mathrm{g} \mathrm{L}^{-1}$. Te NPs concentrations from supernatants of $M$. humilis and T. harzianum were $95 \mu \mathrm{g} \mathrm{L}^{-1}$ and $174 \mu \mathrm{g} \mathrm{L}^{-1}$ respectively. After a 30-day incubation, particle diameters and concentrations were similar to those found after 20 days (Fig. 6b).

Amounts of Se and Te associated with fungal biomass were determined after acid digestion and extraction. Se accumulation values for A. pullulans, M. humilis, T. harzianum and P. glomerata were $12,55,29$ and $3 \mu \mathrm{g} \mathrm{g}^{-1}$, respectively, corresponding to recoveries of $23.1,49.9,41.4$ and $8.9 \%$ (Table 3). Te concentrations were 20,1500, 1370 and 

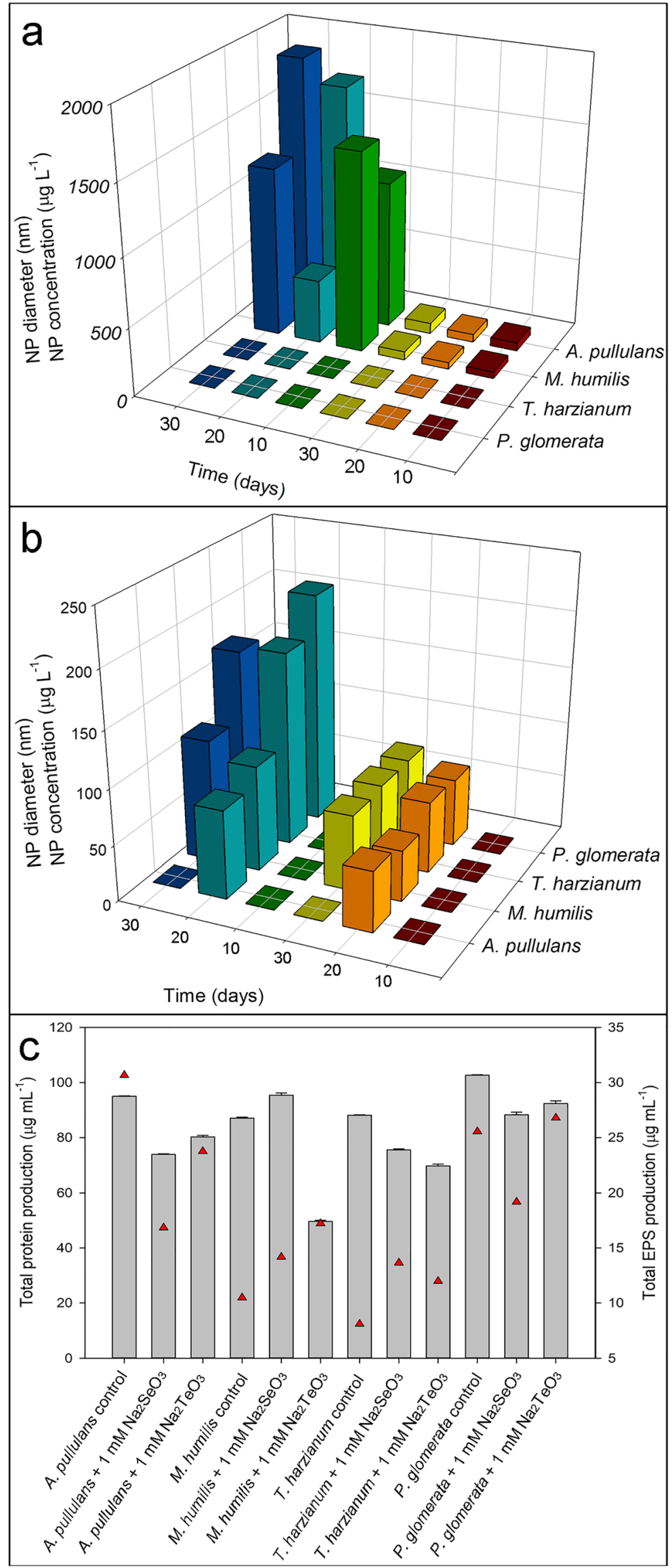
Fig. 6 Diameters and concentrations of Se and Te NPs, total extracellular protein and exopolysaccharide production by the test fungi grown in AP1 liquid medium amended with $1 \mathrm{mM} \mathrm{Na}_{2} \mathrm{SeO}_{3}$ or $\mathrm{Na}_{2} \mathrm{TeO}_{3}$. Diameters and concentrations of (a) Se and (b) Te nanoparticles generated after growth of A. pullulans, M. humilis, T. harzianum, and P. glomerata in the presence of $1 \mathrm{mM} \mathrm{Na}_{2} \mathrm{SeO}_{3}$ or $\mathrm{Na}_{2} \mathrm{TeO}_{3}$. The graphs show diameters of Se and Te NPs after growth for $(\square) 10$ days, $(\square) 20$ days and $(\square) 30$ days, and concentration of Se and Te NPs after growth for $(\square) 10$ days,

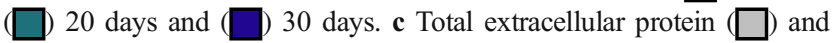
exopolysaccharide $(\triangle)$ concentration after growth of test fungi with $1 \mathrm{mM} \mathrm{Na} \mathrm{SeO}_{3}$ or $\mathrm{Na}_{2} \mathrm{TeO}_{3}$. All test fungi were grown in AP1 liquid medium at $125 \mathrm{rpm}$ at $25^{\circ} \mathrm{C}$ in the dark. All measurements are from at least three replicates and error bars indicate the standard error of the mean

$670 \mu \mathrm{g} \mathrm{g}^{-1}$, respectively, with corresponding recoveries of $66.7,65.5,80.1$ and $98.5 \%$ (Table 3).

\section{Extracellular protein and exopolysaccharide concentrations}

The presence of $\mathrm{Na}_{2} \mathrm{SeO}_{3}$ and $\mathrm{Na}_{2} \mathrm{TeO}_{3}$ had an effect on extracellular protein secretion. Compared with the control, the amount of extracellular protein decreased slightly after growth with $1 \mathrm{mM} \mathrm{Na}_{2} \mathrm{SeO}_{3}$ and $\mathrm{Na}_{2} \mathrm{TeO}_{3}$. Most of the test fungal strains produced similar amounts of protein in control medium at around $90-100 \mu \mathrm{g} \mathrm{mL}^{-1}$ (Fig. 6c). In the presence of $1 \mathrm{mM}$ $\mathrm{Na}_{2} \mathrm{SeO}_{3}$ and $\mathrm{Na}_{2} \mathrm{TeO}_{3}$, the protein concentration for A. pullulans dropped to $73 \mu \mathrm{g} \mathrm{mL}^{-1}$ and $80 \mu \mathrm{g} \mathrm{mL}^{-1}$, respectively, from $95 \mu \mathrm{g} \mathrm{mL}^{-1}$; the protein concentration for T. harzianum dropped to $75 \mu \mathrm{g} \mathrm{mL}^{-1}$ and $69 \mu \mathrm{g} \mathrm{mL}^{-1}$, respectively, from $88 \mu \mathrm{g} \mathrm{mL}^{-1}$; the protein concentration for P. glomerata dropped to $88 \mu \mathrm{g} \mathrm{mL}^{-1}$ and $92 \mu \mathrm{g} \mathrm{mL}^{-1}$, respectively, from $102 \mu \mathrm{g} \mathrm{mL}^{-1}$ (Fig. 6c). There was a significant protein concentration decrease for $M$. humilis from 87 to $49 \mu \mathrm{g} \mathrm{mL}^{-1}$ in the presence of $1 \mathrm{mM} \mathrm{Na}_{2} \mathrm{TeO}_{3}$ (Fig. 6c).

The exopolysaccharide concentration patterns did not correlate with extracellular protein concentration patterns, and varied between different species. A. pullulans produced the most exopolysaccharide at $30 \mu \mathrm{g} \mathrm{mL}^{-1}$, while in the presence of $1 \mathrm{mM} \mathrm{Na}_{2} \mathrm{SeO}_{3}$ and $1 \mathrm{mM} \mathrm{Na}_{2} \mathrm{TeO}_{3}$, it dropped to $16 \mu \mathrm{g}$ $\mathrm{mL}^{-1}$ and $23 \mu \mathrm{g} \mathrm{mL}^{-1}$, respectively, after a 30-day incubation (Fig. 6c). Exopolysaccharide production by M. humilis was enhanced by the presence of $1 \mathrm{mM} \mathrm{Na}_{2} \mathrm{TeO}_{3}$ yielding $17 \mu \mathrm{g}$ $\mathrm{mL}^{-1}$ (Fig. 6c). Exopolysaccharide production by T. harzianum was the lowest compared with the other strains. The concentration of exopolysaccharide from $P$. glomerata with $1 \mathrm{mM} \mathrm{Na}_{2} \mathrm{SeO}_{3}$ and $1 \mathrm{mM} \mathrm{Na}_{2} \mathrm{TeO}_{3}$ were similar to the control $\left(25 \mu \mathrm{g} \mathrm{mL}^{-1}\right)$, being $19 \mu \mathrm{g} \mathrm{mL}^{-1}$ and $26 \mu \mathrm{g}$ $\mathrm{mL}^{-1}$, respectively (Fig. 6c).

\section{X-ray powder diffraction}

The selenium-containing particles associated with A. pullulans, M. humilis, T. harzianum and P. glomerata showed an excellent match to reference patterns for elemental selenium $(\mathrm{Se})$, while downeyite $\left(\mathrm{SeO}_{2}\right)$ was only detected with T. harzianum (Fig. 7a). The tellurium-containing particles associated with A. pullulans, M. humilis, T. harzianum and P. glomerata showed elemental tellurium (Te), and tellurium oxide was detected in the particles generated by T. harzianum and M. humilis (Fig. 7b). The XRD patterns displayed here are consistent with earlier reports (Zare et al. 2012). Other unidentified peaks are possibly due to organic impurities present in the samples, and may indicate the presence of capping agents. Such unidentified peaks in XRD patterns are also apparent in other Te NPs studies (Zare et al. 2012).

\section{Discussion}

\section{$\mathrm{SeO}_{3}{ }^{2-}$ - and $\mathrm{TeO}_{3}{ }^{2-}$-reducing microorganisms}

This work has shown that A. pullulans, M. humilis, $T$. harzianum and $P$. glomerata were capable of reducing both selenite and tellurite to elemental selenium and elemental tellurium respectively. However, not all fungi could reduce selenate (Fig. 1). Biogenic elemental selenium nanoparticles are red in colour while commercial elemental selenium particles of various sizes are black, the colour difference between different selenium particle sizes being attributed to the collective oscillation of free conduction electrons induced by an interacting electromagnetic field, which is called the surface plasmon resonance peak: this phenomenon results from the promotion or excitation of relatively loosely held electrons to higher electrical conductivity (Dwivedi et al. 2011, 2013). The reduction of $\mathrm{SeO}_{3}{ }^{2-}$ and $\mathrm{TeO}_{3}{ }^{2-}$ to $\mathrm{Se}^{0}$ and $\mathrm{Te}^{0}$ was generally accompanied by inhibition of fungal growth as measured by colony expansion (Gharieb et al. 1995, 1999), Among the test fungi, T. harzianum apparently showed better selenite and tellurite tolerance according to growth inhibition measurement (Table 1). However, tolerance indices based on biomass yield showed that M. humilis and T. harzianum produced higher biomass yields when grown with $\mathrm{SeO}_{3}{ }^{2-}$ and $\mathrm{TeO}_{3}{ }^{2-}$ comparable to that of the control (Table 2). Previous work showed that Penicillium citrinum exhibited no significant decrease in biomass yield in the presence of $\mathrm{NaTeO}_{3}$ (127 mg Te L ${ }^{-1}$ ), although a Fusarium sp. did show a significant reduction (Gharieb et al. 1999). Thus, different degrees of inhibition of fungal growth in the presence of $\mathrm{SeO}_{3}{ }^{2-}$ and $\mathrm{TeO}_{3}{ }^{2-}$ were detected from both growth inhibition measurement and tolerance indices among the test strains. Two main hypotheses have been proposed for selenium and tellurium biotransformations by microorganisms. Several sulfatereducing bacteria (e.g. Desulfovibrio desulfuricans, Desulfomicrobium norvegicum, Chromatium spp.) can reduce selenium oxyanions to elemental selenium or produce 
methylated selenium products during the reduction of $\mathrm{SO}_{4}{ }^{2-}$ to $\mathrm{S}^{2-}$. The reduction rates of $\mathrm{SO}_{4}{ }^{2-}$ and $\mathrm{SeO}_{4}{ }^{2-}$ were closely related to their concentrations (Zehr and Oremland 1987; Hockin and Gadd 2003; Baesman et al. 2007). Another work has demonstrated that reduction of selenium oxyanions can occur by pathways separate from sulfate reduction (Oremland et al. 1989, 1994, 2004). Dissimilatory Sereducing bacteria employ various electron donors to reduce selenium oxyanions, which include sugars, organic acids, alcohols, hydrogen and humic substances (Kashiwa et al. 2000; Zhang et al. 2004, 2008, 2015; Chung et al. 2006; Astratinei et al. 2006).

Previous research has demonstrated that $\mathrm{SeO}_{3}{ }^{2-}-, \mathrm{SeO}_{4}{ }^{2-}$ and/or $\mathrm{TeO}_{3}{ }^{2-}$ - and $\mathrm{TeO}_{4}{ }^{2-}$-reducing bacteria are frequently isolated from natural microbial communities (Zhang et al. 2004; Jain et al. 2014, 2015; Tan et al. 2016). The application of microbial consortia for selenium oxyanion removal from contaminated matrices has been developed, such as the ABMet@biofilter system, electro-biochemical reactors (EBR), biofilm reactors (BSeR), membrane biofilm reactors (MBfR), upflow anaerobic sludge blanket reactors (UASB) and sequencing batch reactors (SBR) (Tan et al. 2016). However, potential applications for tellurium oxyanion removal or recovery has received limited attention (Tan et al. 2016). Extracellular polymeric substances including polysaccharides can also play a role in the formation of biogenic elemental selenium and tellurium nanoparticles (BioSeNPs/ BioTeNPs). Functional groups characteristic of protein and carbohydrate are found on BioSeNPs, suggesting that a coating formed by EPS can determine colloidal properties and surface charge (Zhang et al. 2004; Jain et al. 2014, 2015). Previous research has also confirmed the complete bioconversion of $\mathrm{TeO}_{3}{ }^{2-}$ to its elemental state in the form of Tenanostructures associated with the loosely bound EPS fraction surrounding activated sludge, which suggested a pivotal role played by EPS and its functional groups in the genesis of tellurium nanoparticles (Mal et al. 2017). The appearance of a bright red and black colour indicates the formation of amorphous elemental selenium and tellurium particles. It is likely that selenite and tellurite were reduced through a series of steps. Some of the added selenite or tellurite in the fungal culture medium is taken up by the selected fungi and reduced intracellularly. Reduction to elemental selenium and tellurium also can occur through secreted protein, surface constituents such as glycoproteins, extracellular polymeric substances, such as polysaccharide, protein, nucleic acids, humic substances, with functional groups such as carboxylic, phosphoryl amino and hydroxyl groups (Tsuneda et al. 2003, Guibaud et al. 2008, Holmes and Gu 2016). Extracellular polymeric substances can act as capping agents and control the size and shape of elemental selenium and tellurium NPs, as well as enhancing stability. The stability of Se and Te NPs is important in considering possible toxicity from released ions. In our work, the Se and Te NPs appeared to be stable in the longer term and still retained their shapes and sizes after 6 months. The possibility to remove and recover selenium and tellurium nanoparticles associated with the EPS fraction suggests a new approach for biorecovery of Se or Te.

\section{Formation of elemental Se, Te, selenium oxide and tellurium oxide}

This work has demonstrated the formation of elemental Se and Te by A. pullulans, M. humilis, T. harzianum and $P$. glomerata, together with selenium- and telluriumcontaining oxide nanoparticles in $T$. harzianum, and tellurium-containing oxide nanoparticles in M. humilis. Several researchers have investigated mechanisms of microbial formation of Se and Te nanoparticles (e.g. Zhang et al. 2001; Prakash et al. 2009; Dhanjal and Cameotra 2010; Bajaj et al. 2012). The formation of selenium and tellurium nanoparticles can be associated with protein which affects the formation and growth of nanoparticles and can control their size and distribution (Dobias et al. 2011; Hunter 2014a,b). However, this is apparently the first time that selenium oxide and tellurium oxide have been found after metalloid oxyanion interaction with fungi, together with elemental selenium and tellurium. In addition, spindle-shaped tellurium particles in the nano-size range were observed in fungal culture supernatants, of length $\sim 190 \mathrm{~nm}$ and width $<30 \mathrm{~nm}$, most similar in size and shape. Rod-shaped tellurium nanoparticles have been observed with bacteria, inside cells or on cell surfaces (Oremland et al. 2004, Baesman et al. 2007, Pearce et al. 2011, Kim et al. 2012, Zare et al. 2012, Forootanfar et al. 2015, Borghese et al. 2016, Espinosa-Ortiz et al. 2017). Bacillus selenitireducens was capable of reducing tellurium as tellurate or tellurite to rosette-aggregated $\mathrm{Te}^{0}$ rods with particle sizes of $30 \mathrm{~nm} \times$ $200 \mathrm{~nm}$ and selenium as selenite or selenate to $\mathrm{Se}^{0}$ with a spherical particle size of $200 \mathrm{~nm}$ (Oremland et al. 2004, Baesman et al. 2007). Previous research has also demonstrated that Bacillus selenitireducens (Baesman et al. 2007), Bacillus sp. (Zare et al., 2012), Pseudomonas pseudoalcaligenes (Forootanfar et al. 2015), Rhodobacter capsulatus (Borghese et al. 2016), Shewanella oneidensis (Kim et al. 2012), Shewanella barnesii (Baesman et al. 2007), Bacillus beveridgei (Pearce et al. 2011) and Phanerochaete chrysosporium (Espinosa-Ortiz et al. 2017) can generate Te nanorods, nanospheres and needle- and splinter-like nanoparticles.

Two important bioremediation or biorecovery approaches are involved in selenium and tellurium transformations by fungi: reduction and methylation. Microbial methylation of inorganic Se and Te oxyanions to volatile species offers an approach for bioremediation of metalloid-polluted soils which has been clearly demonstrated for Se (Zare et al. 2012; Nancharaiah and Lens 2015). Extracellular production of 
Table 3 Se and Te NPs concentration and yield from the test fungi grown with $1 \mathrm{mM} \mathrm{Na}_{2} \mathrm{SeO}_{3}$ or $1 \mathrm{mM} \mathrm{Na}_{2} \mathrm{TeO}_{3}$. All test fungi were grown for 30 days in AP1 media at $125 \mathrm{rpm}$ at $25^{\circ} \mathrm{C}$ in the dark. Se/Te extraction concentration indicates $\mathrm{Se} / \mathrm{Te} \mathrm{NP}$ concentration generated by fungi; Se/Te digestion concentration indicates $\mathrm{Se} / \mathrm{Te}$ taken up by the fungal biomass (as $\mathrm{g}$ fresh $\mathrm{wt}^{-1}$ ). All measurements are from at least three replicates

\begin{tabular}{|c|c|c|c|c|c|c|}
\hline & $\begin{array}{l}\text { Se extraction } \\
\text { concentration }\left(\mu \mathrm{g} \mathrm{g}^{-1}\right)\end{array}$ & $\begin{array}{l}\text { Se digestion } \\
\text { concentration }\left(\mu \mathrm{g} \mathrm{g}^{-1}\right)\end{array}$ & $\begin{array}{l}\text { Se NP yield } \\
(\%)\end{array}$ & $\begin{array}{l}\text { Te extraction } \\
\text { concentration }\left(\mu \mathrm{g} \mathrm{g}^{-1}\right)\end{array}$ & $\begin{array}{l}\text { Te digestion } \\
\text { concentration }\left(\mu \mathrm{g} \mathrm{g}^{-1}\right)\end{array}$ & $\begin{array}{l}\text { Te NP yield } \\
(\%)\end{array}$ \\
\hline A. pullulans & $12.0 \pm 0.08$ & $38.8 \pm 0.11$ & 23.1 & $20 \pm 0.02$ & $10 \pm 0.12$ & 66.7 \\
\hline M. humilis & $55.4 \pm 0.65$ & $55.6 \pm 0.14$ & 49.9 & $1500 \pm 1.3$ & $790 \pm 3.6$ & 65.5 \\
\hline T. harzianum & $28.8 \pm 0.14$ & $40.9 \pm 0.37$ & 41.4 & $1370 \pm 3.2$ & $340 \pm 4.2$ & 80.1 \\
\hline P. glomerata & $2.9 \pm 0.12$ & $29.6 \pm 0.09$ & 8.9 & $670 \pm 2.1$ & $10 \pm 0.12$ & 98.5 \\
\hline
\end{tabular}

BioSeNPs and BioTeNPs are mainly carried out by Se- and Te-respiring bacteria through dissimilatory metalloid reduction. In contrast, intracellular production of BioSeNPs and BioTeNPs may comprise a detoxification mechanism for selenium and tellurium oxyanions (Nancharaiah and Lens 2015). However, elemental selenium and tellurium may show antimicrobial activity as these NPs have large specific surface areas with strong reactive sites, although elemental Se or Te are generally regarded as of low or no toxicity (Zare et al. 2012; Nancharaiah and Lens 2015). The size and shape of selenium and tellurium nanoparticles generated from fungi are dependent on various capping and dispersing agents (Dobias et al. 2011). Biosynthesis of extracellular nanoparticles is usually achieved in two steps, reduction and precipitation, followed by nucleation and aggregation of crystal structures: nanoparticles attached to fungal surfaces may perturb metabolic functions, such as respiration (Afkar et al. 2003). The reduction of selenium oxyanions in bacteria can be catalysed by reductases, including nitrite reductase, sulfite reductase and DMSO (dimethyl sulfoxide) reductase (Harrison et al. 1984; DeMoll-Decker and Macy 1993; Afkar et al. 2003). The $\mathrm{SeO}_{4}{ }^{2-}$-respiring bacteria Thauera selenatis and Pseudomonas selenitipraecipitans strain CA-5 were capable of reducing both $\mathrm{SeO}_{3}{ }^{2-}$ and $\mathrm{SeO}_{4}{ }^{2-}$ to $\mathrm{Se}^{0}$ through periplasmic $\mathrm{NO}_{3}{ }^{-}$reductase activity (DeMoll-Decker and Macy 1993; Hunter and Manter 2009). However, in Shewanella oneidensis MR-1, which also has the ability to reduce $\mathrm{SeO}_{3}{ }^{2-}$ to $\mathrm{Se}^{0}$, $\mathrm{SeO}_{3}{ }^{2-}$-reducing ability had no direct connection to nitrate or nitrite reductase. Deletions of genes encoding nitrate reductase (napA), nitrite reductase ( $n r f A)$ and two periplasmic electron transfer mediators for anaerobic respiration (mtrA and $d m s E$ ) did not affect the ability to reduce selenium oxyanions (Li et al. 2014). The mechanisms of bioreduction of selenate and selenite to elemental selenium by bacteria has been extensively examined, but the biological processes responsible for selenite and tellurite reduction by fungi have been relatively neglected.

Particle sizes obtained from SEM measurements were lower than those estimated from SP-ICP-MS measurements. This is due to the fact that the particle sizes obtained by SP-ICP-MS are augmented substantially by the hydrated capping agents, such as proteins, and solvation effects. Selenium and tellurium nanoparticles generated by microorganisms have properties that are difficult to mimic by chemical and physical approaches (Espinosa-Ortiz et al. 2017). Fungal generated elemental selenium and tellurium tended to show a welldispersed behaviour and the nanoparticles were not in direct contact even within aggregates, indicating stabilisation of the nanoparticles by a capping agent.

Oxidation of reduced selenium species may be relevant with respect to the availability of selenium as a trace element. Various works have indicated that microorganisms are capable of aerobic oxidation of $\mathrm{Se}^{0}$ and $\mathrm{SeO}_{3}{ }^{2-}$ in the soil. Microbial oxidation of elemental selenium occurred in soil slurries and bacterial cultures transformed elemental selenium into both selenite $\left(\mathrm{SeO}_{3}{ }^{2-}\right)$ and selenate $\left(\mathrm{SeO}_{4}{ }^{2-}\right)$, with selenite being the dominant product. This indicated that microbial oxidation in soils is partly constrained by adsorption of selenite on surfaces of soil components (Dowdle and Oremland 1998). Earlier evidence suggested that Acidithiobacillus ferrooxidans could use copper selenide oxidation as a source of energy (Torma and Habashi 1972). Bacillus megaterium can also oxidize $\mathrm{Se}^{0}$ to $\mathrm{SeO}_{3}{ }^{2-}$ with traces of $\mathrm{SeO}_{4}{ }^{2-}$ (Nancharaiah and Lens 2015). However, this is the first time that selected fungal strains have shown selenite oxide and tellurite oxide formation together with elemental selenium and tellurium. This implies that oxidation, reduction and methylation of selenium and tellurium species can occur during interaction with fungal species.

In conclusion, Se- or Te-species removal by fungi is accomplished through intracellular uptake or interaction with surface biomolecules such as extracellular proteins, amino acids and extracellular polymeric substances, while cellular biotransformation of these oxyanions leads to reduction to elemental selenium and tellurium or transformation to selenium oxide and tellurium oxide. The application of biologically induced, semi-synthetic production of selenium and tellurium nanoparticles, 

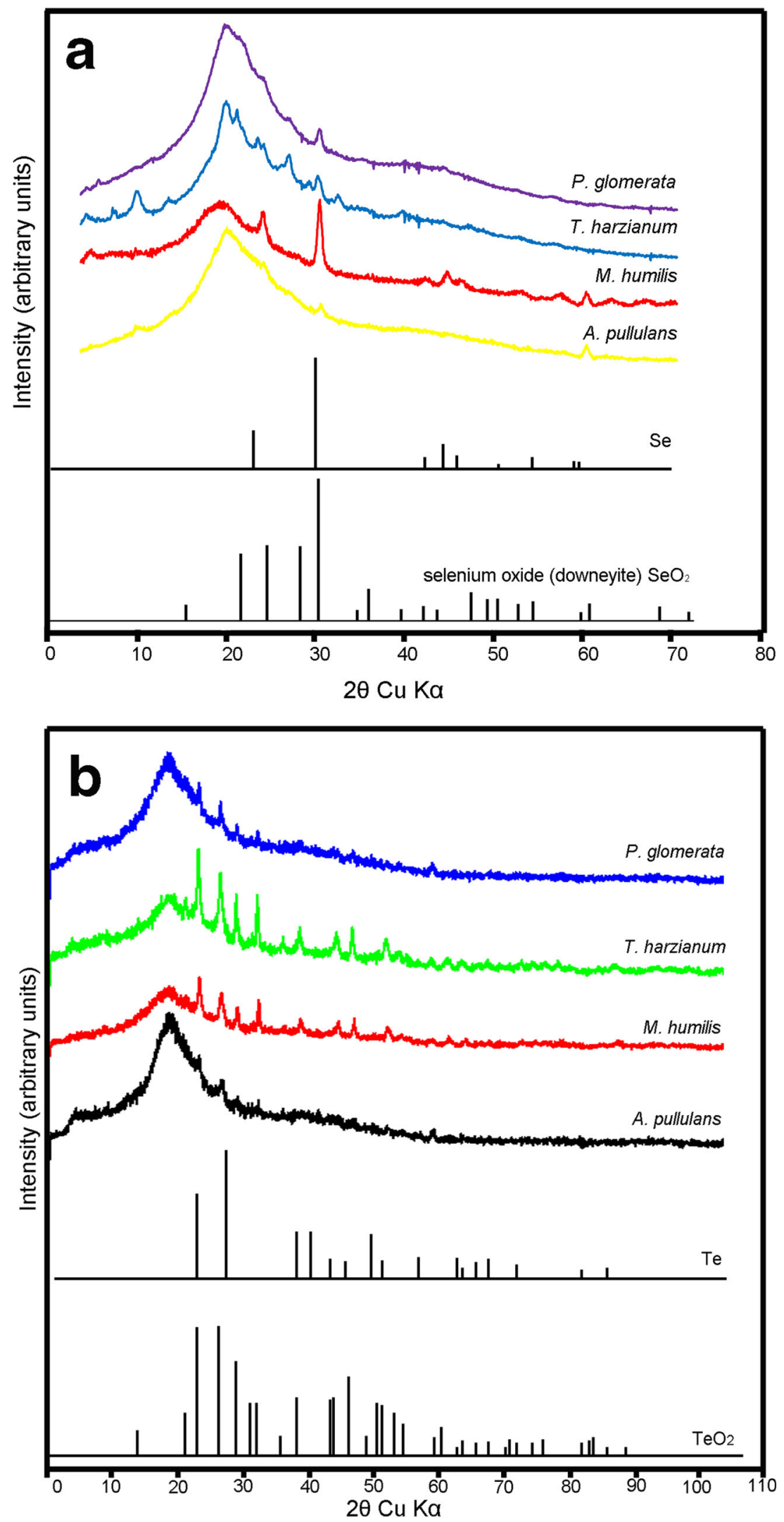

together with generation of selenium oxide and tellurium oxide could be a promising addition to current chemical or physical processes for nanoparticle production. Both elemental selenium and tellurium nanoparticles have 
Fig. 7 X-ray powder diffraction patterns of particles formed with (a) $1 \mathrm{mM}$ sodium selenite- or (b) sodium tellurite-amended AP1 liquid medium after fungal growth at $25{ }^{\circ} \mathrm{C}$ in the dark at $125 \mathrm{rpm}$ for 30 days. Patterns for dominant components are shown, as well as the particles produced as a result of fungal activity: elemental selenium (Se) and (a) downeyite $\left(\mathrm{SeO}_{2}\right)$, elemental tellurium (Te) and (b) tellurium oxide $\left(\mathrm{TeO}_{2}\right)$. a Diffraction patterns collected from particles harvested from A. pullulans, $M$. humilis, T. harzianum, and $P$. glomerata grown with $1 \mathrm{mM} \mathrm{Na}_{2} \mathrm{SeO}_{3}$. b Diffraction patterns collected from particles harvested from A. pullulans, M. humilis, T. harzianum and $P$. glomerata grown with $1 \mathrm{mM} \mathrm{Na}_{2} \mathrm{TeO}_{3}$. Typical diffraction patterns are shown from one of several determinations

been shown to protect organisms from DNA oxidation (Wang et al. 2007; Tran and Webster 2011; Huang et al. 2016), as well as possibly acting as promising antimicrobial and anticancer agents (Ahmad et al. 2015; Zonaro et al. 2015; Cremonini et al. 2016; Piacenza et al. 2017). Bioremediation of selenium- and telluriumpolluted environments and biorecovery of elemental SeNPs and TeNPs also suggest an environmentally sustainable choice to treat contaminated soils, groundwater, wastewater, leachates and sediments (Piacenza et al. 2017). A challenge in the biogenic production of selenium and tellurium nanoparticles is their purification from fungal biomass, because the formation of selenium and tellurium nanoparticles can be achieved both intracellularly and extracellularly: separation of particles from biomass without altering their properties, shapes and sizes is challenging. However, this work has demonstrated the secretion of Se or Te nanoparticles into the culture medium, and also their formation by reactions between selenite and tellurite and spent fungal culture supernatants. Further investigation could be focused on properties of biogenic selenium and tellurium NPs in terms of surface absorbing activity, reactivity, selectivity and sustainable treatment capability to optimise their industrial application potential for bioremediation and biorecovery.

Acknowledgements GMG gratefully acknowledges research support from Natural Environment Research Council (NE/M010910/1) under the NERC Security of Supply of Mineral Resources Grant Programme: Tellurium and Selenium cycling and supply (TeaSe). GMG also gratefully acknowledges additional support of the Geomicrobiology Group from NERC (NE/M011275/1 $\left.\left(\mathrm{COG}^{3}\right)\right)$. The authors also gratefully acknowledge the help of Dr. Yongchang Fan (Materials and Photonics Systems Group, University of Dundee, Dundee, DD1 5EH, Scotland UK) for assistance with scanning electron microscopy, and Drs. Paul Schofield and Jens Najorka for assistance with X-ray diffraction (Department of Mineralogy, Natural History Museum, London).

\section{Compliance with ethical standards}

Conflict of interest The authors declare no conflict of interest.

Ethics approval This article does not contain any studies with human participants or animals performed by any of the authors.
Open Access This article is distributed under the terms of the Creative Commons Attribution 4.0 International License (http:// creativecommons.org/licenses/by/4.0/), which permits unrestricted use, distribution, and reproduction in any medium, provided you give appropriate credit to the original author(s) and the source, provide a link to the Creative Commons license, and indicate if changes were made.

\section{References}

Aborode FA, Raab A, Foster S, Lombi E, Maher W, Krupp EM, Feldmann J (2015) Selenopeptides and elemental selenium in Thunbergia alata after exposure to selenite: quantification method for elemental selenium. Metallomics 7:1056-1066

Afkar E, Lisak J, Saltikov C, Basu P, Oremland RS, Stolz JF (2003) The respiratory arsenate reductase from Bacillus selenitireducens strain MLS10. FEMS Microbiol Lett 226:107-112

Ahluwalia V, Kumar J, Sisodia R, Shakil NA, Walia S (2014) Green synthesis of silver nanoparticles by Trichoderma harzianum and their bio-efficacy evaluation against Staphylococcus aureus and Klebsiella pneumonia. Ind Crop Prod 55:202-206

Ahmad MS, Yasser MM, Sholkamy EN, Ali AM, Mehanni MM (2015) Anticancer activity of biostabilized selenium nanorods synthesized by Streptomyces bikiniensis strain Ess_amA-1. Int J Nanomedicine 10:3389-3401

Astratinei V, Lens PNL, Van Hullebusch ED (2006) Bioconversion of selenate in methanogenic anaerobic granular sludge. J Environ Qual 35:1873-1883

Baesman SM, Bullen TD, Dewald J, Zhang D, Curran S, Islam FS, Beveridge TJ, Oremland RS (2007) Formation of tellurium nanocrystals during anaerobic growth of bacteria that use $\mathrm{Te}$ oxyanions as respiratory electron acceptors. Appl Environ Microbiol 73:2135-2143

Bajaj M, Schmidt S, Winter J (2012) Formation of Se(0) nanoparticles by Duganella sp. and Agrobacterium sp. isolated from Se-laden soil of North-East Punjab, India. Microb Cell Factories 11:64

Birla SS, Tiwari VV, Gade AK, Ingle AP, Yadav AP, Rai MK (2009) Fabrication of silver nanoparticles by Phoma glomerata and its combined effect against Escherichia coli, Pseudomonas aeruginosa and Staphylococcus aureus. Lett Appl Microbiol 48:73-179

Borghese R, Brucale M, Fortunato G, Lanzi M, Mezzi A, Valle F, Cavallini M, Zannoni D (2016) Extracellular production of tellurium nanoparticles by the photosynthetic bacterium Rhodobacter capsulatus. J Hazard Mater 309:202-209

Brady JM, Tobin JM, Gadd GM (1996) Volatilization of selenite in aqueous medium by a Penicillium species. Mycol Res 100:955-961

Bullock LA, Parnell J, Perez M, Feldmann J, Armstrong JM (2017) Selenium and other trace element mobility in waste products and weathered sediments at Parys Mountain copper mine, Anglesey, UK. Minerals 7:229

Chasteen TG, Bentley R (2003) Biomethylation of selenium and tellurium: microorganisms and plants. Chem Rev 103:1-26

Chung J, Nerenberg R, Rittmann BE (2006) Bioreduction of selenate using a hydrogen-based membrane biofilm reactor. Environ Sci Technol 40:1664-1671

Cremonini E, Zonaro E, Donini M, Lampis S, Boaretti M, Disu S, Melotti P, Lleo MM, Vallini G (2016) Biogenic selenium nanoparticles: characterization, antimicrobial activity and effects on human dendritic cells and fibroblast. Microb Biotechnol 9:758-771

DeMoll-Decker H, Macy JM (1993) The periplasmic nitrite reductase of Thauera selenatis may catalyze the reduction of selenite to elemental selenium. Arch Microbiol 160:241-247 
Dhanjal S, Cameotra SS (2010) Aerobic biogenesis of selenium nanospheres by Bacillus cereus isolated from coalmine soil. Microb Cell Factories 9:52

Dobias J, Suvorova EI, Bernier-Latmani R (2011) Role of proteins in controlling selenium nanoparticle size. Nanotechnology 22:195605

Dowdle PR, Oremland RS (1998) Microbial oxidation of elemental selenium in soil slurries and bacterial cultures. Environ Sci Technol 32: 3749-3755

Dubois M, Gilles KA, Hamilton JK, Rebers PA, Smith F (1956) Calorimetric method for determination of sugars and related substances. Anal Chem 28:350-356

Dwivedi C, Shah CP, Singh K, Kumar M, Bajaj PN (2011) An organic acid-induced synthesis and characterization of selenium nanoparticles. J Nanotechnol 2011:1-6

Dwivedi S, Alkhedhairy AA, Ahamed M, Musarrat J (2013) Biomimetic synthesis of selenium nanospheres by bacteria strain JS-11 and its role as a biosensor for nanotoxicity assessment: a novel Se-bioassay. PLoS One 8:e57404

Espinosa-Ortiz EJ, Gonzalez-Gil G, Saikaly PE, van Hullebusch ED, Lens PNL (2015a) Effects of selenium oxyanions on the white-rot fungus Phanerochaete chrysosporium. Appl Microbiol Biotechnol 99:2405-2418

Espinosa-Ortiz EJ, Rene ER, van Hullebusch ED, Lens PNL (2015b) Removal of selenite from wastewater in a Phanerochaete chrysosporium pellet based fungal bioreactor. Int Biodeterior Biodegradation 102:361-369

Espinosa-Ortiz EJ, Pechaud Y, Lauchnor E, Rene ER, Gerlach R, Peyton BM, van Hullebusch ED, Lens PNL (2016a) Effect of selenite on the morphology and respiratory activity of Phanerochaete chrysosporium biofilms. Bioresour Technol 210:138-145

Espinosa-Ortiz EJ, Rene ER, Pakshirajan K, van Hullebusch ED, Lens PNL (2016b) Fungal pelleted reactors in wastewater treatment: applications and perspectives. Chem Eng J 283:553-571

Espinosa-Ortiz EJ, Shakya M, Jain R, Rene ER, van Hullebusch ED, Lens PNL (2016c) Sorption of zinc onto elemental selenium nanoparticles immobilized in Phanerochaete chrysosporium pellets. Environ Sci Pollut Res Int 23:21619-21630

Espinosa-Ortiz EJ, Rene ER, Guyot F, van Hullebusch ED, Lens PNL (2017) Biomineralization of tellurium and selenium-tellurium nanoparticles by the white-rot fungus Phanerochaete chrysosporium. Int Biodeterior Biodegradation 124:258-266

Eswayah AS, Smith TJ, Gardiner PH (2016) Microbial transformations of selenium species of relevance to bioremediation. Appl Environ Microbiol 82:4848-4859

Forootanfar H, Amirpour-Rostami S, Jafari M, Forootanfar A, Yousefizadeh Z, Shakibaie M (2015) Microbial-assisted synthesis and evaluation the cytotoxic effect of tellurium nanorods. Mater Sci Eng C Mater Biol Appl 49:183-189

Freitas AL, Moura GF, Lima MAB, Souza PM, Silva CAA, Tajaju GMC, Nascimento AE (2011) Role of the morphology and polyphosphate in Trichoderma harzianum related to cadmium removal. Molecules 16:2486-2500

Gadd GM (1993) Microbial formation and transformation of organometallic and organometalloid compounds. FEMS Microbiol Rev 11: 297-316

Gade A, Gaikwad S, Duran N, Rai M (2013) Green synthesis of silver nanoparticles by Phoma glomerata. Micron 59:52-59

George MW (2004) Minerals yearbook 2004: Selenium and tellurium. US Geol Surv 65:1-8

Gharieb MM, Gadd GM (2004) The kinetics of ${ }^{75}[\mathrm{Se}]$-selenite uptake by Saccharomyces cerevisiae and the vacuolization response to high concentrations. Mycol Res 108:1415-1422

Gharieb MM, Wilkinson SC, Gadd GM (1995) Reduction of selenium oxyanions by unicellular, polymorphic and filamentous fungi: cellular location of reduced selenium and implications for tolerance. J Ind Microbiol 14:300-311
Gharieb MM, Kierans M, Gadd GM (1999) Transformation and tolerance of tellurite by filamentous fungi: accumulation, reduction, and volatilization. Mycol Res 103:299-305

Grondona I, Hermosa R, Tejada M, Gomis MD, Mateos PF, Bridge PD, Monte E, Garcia-Acha I (1997) Physiological and biochemical characterization of Trichoderma harzianum, a biological control agent against soilborne fungal plant pathogens. Appl Microbiol Biotechnol 63:3189-3198

Guibaud G, Bordas F, Saaid A, D'abzac P, Van Hullebusch E (2008) Effect of $\mathrm{pH}$ on cadmium and lead binding by extracellular polymeric substances (EPS) extracted from environmental bacterial strains. Colloids Surf B: Biointerfaces 63:48-54

Harrison G, Curle C, Laishley EJ (1984) Purification and characterization of an inducible dissimilatory type sulfite reductase from Clostridium pasteurianum. Arch Microbiol 138:72-78

Haug A, Graham RD, Christophersen OA, Lyons GH (2007) How to use the world's scarce selenium resources efficiently to increase the selenium concentration in food. Microb Ecol Health Dis 19:209-228

Hockin SL, Gadd GM (2003) Linked redox precipitation of sulfur and selenium under anaerobic conditions by sulfate-reducing bacterial biofilms. Appl Environ Microbiol 69:7063-7072

Holmes AB, Gu FX (2016) Emerging nanomaterials for the application of selenium removal for wastewater treatment. Environ Sci Nano 3: 982-996

Huang W, Wu H, Li X, Chen T (2016) Facile one-pot synthesis of tellurium nanorods as antioxidant and anticancer agents. Chem Asian J 11:2301-2311

Hunter WJ (2014a) A Rhizobium selenitireducens protein showing selenite reductase activity. Curr Microbiol 68:311-316

Hunter WJ (2014b) Pseudomonas seleniipraecipitans proteins potentially involved in selenite reduction. Curr Microbiol 69:69-74

Hunter WJ, Manter DK (2009) Reduction of selenite to elemental red selenium by Pseudomonas sp. strain CA5. Curr Microbiol 58: 493-498

Jacob JM, Lens PNL, Balakrishnan RM (2016) Microbial synthesis of chalcogenide semiconductor nanoparticles: a review. Microb Biotechnol 9:11-21

Jain R, Gonzalez-Gil G, Singh V, van Hullebusch ED, Farges F, Lens PNL (2014) Biogenic selenium nanoparticles, production, characterization and challenges. In: Kumar A, Govil JN (eds) Nanobiotechnology. Studium Press LLC, USA, pp 361-390

Jain R, Jordan N, Weiss S, Foerstendorf H, Heim K, Kacker R, Hübner R, Kramer H, Van Hullebusch ED, Farges F (2015) Extracellular polymeric substances govern the surface charge of biogenic elemental selenium nanoparticles. Environ Sci Technol 49:1713-1720

Kashiwa M, Nishimoto S, Takahashi K, Ike M, Fujita M (2000) Factors affecting soluble selenium removal by a selenate-reducing bacterium Bacillus sp. SF-1. J Biosci Bioeng 89:528-533

Kim DH, Kanaly RA, Hur HG (2012) Biological accumulation of tellurium nanorod structures via reduction of tellurite by Shewanella oneidensis MR-1. Bioresour Technol 125:127-131

Li D, Cheng Y, Wu C, Li W, Li N, Yang Z, Tong Z, Yu H (2014) Selenite reduction by Shewanella oneidensis MR-1 is mediated by fumarate reductase in periplasm. Sci Rep 4:3735

Liang X, Gadd GM (2017) Metal and metalloid biorecovery using fungi. Microb Biotechnol 10:1199-1205

Liu SY, Lo CT, Chen C, Liu MY, Chen JH, Peng KC (2007) Efficient isolation of anthraquinone-derivatives from Trichoderma harzianum ETS 323. J Biochem Biophys Methods 70:391-395

Mal J, Nancharaiah YV, Maheshwari N, van Hullebusch ED, Lens PNL (2017) Continuous removal and recovery of tellurium in an upflow anaerobic granular sludge bed reactor. J Hazard Mater 327:79-88

Mandal D, Bolander ME, Mukhopadhyay D, Sarkar G, Mukherjee P (2006) The use of microorganisms for the formation of metal nanoparticles and their application. Appl Microbiol Biotechnol 69:485492 
Mowll JL, Gadd GM (1984) Cadmium uptake by Aureobasidium pullulans. J Gen Microbiol 130:279-284

Nancharaiah YV, Lens PNL (2015) Ecology and biotechnology of selenium-respiring bacteria. Microbiol Mol Biol Rev 79:61-80

Nandini B, Hariprasad P, Prakash HS, Shetty HS, Geetha N (2017) Trichogenic-selenium nanoparticles enhance disease suppressive ability of Trichoderma against downy mildew disease caused by Sclerospora graminicola in pearl millet. Sci Rep 7:2612

Ollivier PRL, Bahrou A, Church TM, Hanson TE (2011) Aeration controls the reduction and methylation of tellurium by the aerobic, tellurite-resistant marine yeast Rhodotorula mucilaginosa. Appl Environ Microbiol 77:4610-4617

Oremland RS, Hollibaugh JT, Maest AS, Presser TS, Miller LG, Culbertson CW (1989) Selenate reduction to elemental selenium by anaerobic bacteria in sediments and culture: biogeochemical significance of a novel, sulfate-independent respiration. Appl Environ Microbiol 55:2333-2343

Oremland RS, Blum JS, Culbertson CW, Visscher PT, Miller LG, Dowdle P, Strohmaier FE (1994) Isolation, growth, and metabolism of an obligately anaerobic, selenate-respiring bacterium, Strain SES-3. Appl Environ Microbiol 60:3011-3019

Oremland RS, Herbel MJ, Blum JS, Langley S, Beveridge TJ, Ajayan PM, Sutto T, Ellis AV, Curran S (2004) Structural and spectral features of selenium nanospheres produced by Se-respiring bacteria. Appl Environ Microbiol 70:52-60

Ottosson LG, Logg K, Ibstedt S, Sunnerhagen P, Käll M, Blomberg A, Warringer J (2010) Sulfate assimilation mediates tellurite reduction and toxicity in Saccharomyces cerevisae. Eukaryot Cell 9:16351647

Pearce CI, Baesman SM, Blum JS, Fellowes JW, Oremland RS (2011) Nanoparticles formed from microbial oxyanion reduction of toxic group 15 and group 16 metalloids. In: Stolz JF, Oremland RS (eds) Microbial Metal and Metalloid Metabolism: Advances and Applications. ASM Press, Washington DC, pp 297-319

Piacenza E, Presentato A, Zonaro E, Lemire JA, Demeter M, Vallini G, Turner RJ, Lampis S (2017) Antimicrobial activity of biogenically produced spherical Se-nanomaterials embedded in organic material against Pseudomonas aeruginosa and Staphylococcus aureus strains on hydroxyapatite-coated surfaces. Microb Biotechnol 10: 804-818

Prakash NT, Sharma N, Prakash R, Raina KK, Fellowes J, Pearce CI, Lloyd JR, Pattrick RA (2009) Aerobic microbial manufacture of nanoscale selenium: exploiting nature's bio-nanomineralization potential. Biotechnol Lett 31:1857-1862

Ramanujam J, Singh UP (2017) Copper indium gallium selenide based solar cells - a review. Energy Environ Sci 10(6):1306-1319

Sarkar J, Saha S, Dey P, Acharya K (2012) Production of selenium nanorods by phytopathogen, Alternaria alternata. Adv Sci Lett 10:111114
Siddiquee S, Rovina K, Yusof NA, Rodrigues KF, Suryani S (2014) Nanoparticle-enhanced electrochemical biosensor with DNA immobilization and hybridization of Trichoderma harzianum gene. Sens Biosensing Res 2:16-22

Tan LC, Nanchariah YV, van Hullebusch ED, Lens PNL (2016) Selenium: environmental significance, pollution, and biological treatment technologies. Biotechnol Adv 34:886-907

Torma AE, Habashi F (1972) Oxidation of copper (II) selenide by Thiobacillus ferrooxidans. Can J Microbiol 18:1780-1781

Tran PA, Webster TJ (2011) Selenium nanoparticles inhibit Staphylococcus aureus growth. Int J Nanomedicine 6:1553-1558

Tsuneda S, Aikawa H, Hayashi H, Yuasa A, Hirata A (2003) Extracellular polymeric substances responsible for bacterial adhesion onto solid surface. FEMS Microbiol Lett 23:287-292

Vetchinkina E, Loshchinina E, Kursky V, Nikitina V (2013) Reduction of organic and inorganic selenium compounds by the edible medicinal basidiomycete Lentinula edodes and the accumulation of elemental selenium nanoparticles in its mycelium. J Microbiol 51:829-835

Wang H, Zhang J, Yu H (2007) Elemental selenium at nano size possesses lower toxicity without compromising the fundamental effect on selenoenzymes: comparison with selenomethionine in mice. Free Radic Biol Med 42:1524-1533

Zare B, Faramarzi MA, Sepehrizadeh Z, Shakibaie M, Rezaie S, Shahverdi AR (2012) Biosynthesis and recovery of rod-shaped tellurium nanoparticles and their bactericidal activities. Mater Res Bull 47:3719-3725

Zehr JP, Oremland RS (1987) Reduction of selenate to selenide by sulfate-respiring bacteria: experiments with cell suspensions and estuarine sediments. Appl Environ Microbiol 53:1365-1369

Zhang J, Gao X, Zhang L, Bao Y (2001) Biological effects of a nano red elemental selenium. Biofactors 15:27-38

Zhang SY, Zhang J, Wang HY, Chen HY (2004) Synthesis of selenium nanoparticles in the presence of polysaccharides. Mater Lett 58: 2590-2594

Zhang Y, Okeke BC, Frankenberger WT (2008) Bacterial reduction of selenate to elemental selenium utilizing molasses as a carbon source. Bioresour Technol 99:1267-1273

Zhang C, Zhai X, Zhao G, Ren F, Leng X (2015) Synthesis, characterization, and controlled release of selenium nanoparticles stabilized by chitosan of different molecular weights. Carbohydr Polym 134:158166

Zonaro E, Lampis S, Turner RJ, Qazi SJS, Vallini G (2015) Biogenic selenium and tellurium nanoparticles synthetized by environmental microbial isolates efficaciously inhibit bacterial planktonic cultures and biofilms. Front Microbiol 6:584

Publisher's note Springer Nature remains neutral with regard to jurisdictional claims in published maps and institutional affiliations. 